\title{
Sivas Geleneksel Konut Mimarisinin Özellikleri ve Korunma Sorunları
}

\author{
Gülhayat $\mathrm{KILCI}^{1}$, Z. Gediz URAK ${ }^{2}$
}

Öz

Geleneksel konutlar geçmiş nesillerin gündelik sosyal hayatlarının delili olan miras varlıklarıdır. Kentlerin hızla değişim ve dönüşüm gösterdiği günümüzde bu miras varlıklarını belgelemek, korumak ve gelecek nesillere aktarmak bugünkü neslin önemli bir görevi olmuştur. Bu çalışmanın amacı yok olmaya yüz tutmuş Sivas geleneksel konut mirasının günümüze ulaşan son örneklerini belgelemek, mimari özelliklerini değerlendirmek ve koruma sorunlarını ortaya koymaktır. Sivas kent merkezinde gerçekleştirilen alan çalışması sonucu tespit edilen 106 geleneksel konutta envanter çalışması yapılmıştır. Elde edilen bilgiler harita, şekil, grafik ve tablolara dökülerek belgelenmiştir. Söz konusu konutlar geç 19. yüzyıl ve erken 20. yüzyıla tarihlenmektedir. Verilerin değerlendirilmesi bağlamında: geleneksel konutların yerleşim özellikleri, plan özellikleri, cephe organizasyonları, yapım sistemleri ve malzeme kullanım özellikleri, tarihi çevre karakteristikleri ve koruma sorunları aktarılmıştır. Kent ölçeğinden başlayıp yapı ölçeğine kadar yapılan detaylı analizler sonucunda Sivas kent merkezinde sürekli bir geleneksel dokunun varlığından söz edilememektedir. Mevcut yapıların, katmanlı bir kültürel tarihe sahip olan Sivas ilinin, geleneksel Türk Evi'ne dair son örnekleri olması konutların mimari, kültürel ve sosyal değerlerini daha da önemli kılmaktadır. Bu çalışma Sivas geleneksel konutlarının karakteristik özelliklerini ve mevcut durumlarını ortaya koymaktadır ve gelecek çalışmalar için kaynak niteliği taşıması beklenmektedir.

Anahtar Kelimeler: Geleneksel Türk evi, Koruma, Konut, Tipoloji, Sivas

\section{Characteristics of "Sivas" Traditional Housing Architecture and Conservation Problems}

\begin{abstract}
Traditional houses are heritage assets proof of the daily social life of past generations. Documenting, conserving, and transferring of these heritage assets have been an important task of the present generation when cities are rapidly changing and transforming. The aim of this study is to document the recent examples of the traditional house heritage of Sivas, which has been destroyed, to evaluate its architectural characters, and to reveal conservation problems. Inventory studies were conducted in 106 traditional houses identified as a result of fieldwork in Sivas Province. The information obtained is documented through maps, shapes, charts and tables. The houses ages in question are defined to the late 19th century and early 20th century. In
\end{abstract}

\footnotetext{
${ }^{1}$ Gazi Üniversitesi, Mimarlık Bölümü, Ankara.

2 Çankaya Üniversitesi, İç Mimarlık Bölümü, Ankara.

IIlgili Yazar/Corresponding author:gulhayatkilci@gazi.edu.tr
}

Bu çalışma Prof. Dr. Z. Gediz Urak danışmanlığında yürütülmüş “Sivas ili Merkez İlçesi Geleneksel Konutlarının Analiz ve Değerlendirilmesi Bağlamında Koruma Önerilerinin Geliştirilmesi” başıklı yüksek lisans tezinden oluşturulmuştur. 
the context of data evaluation: the settlement organization, plan organization, facade organizations, construction systems-material usage features, historical environmental characteristics, and conservation problems of the traditional residences have been conveyed. As a result of detailed analysis, which started from the city scale to building scale, it is not possible to talk about the existence of a continuous traditional architecture pattern in Sivas Province. The recent examples of the traditional Turkish House of Sivas Province, which has a stratified cultural history, make the architectural, cultural, and social values of these structures even more important. This study reveals the characteristics and current conditions of Sivas' traditional houses and is expected to be a resource for future studies.

\section{Keywords: Turkish Traditional house, Conservation, Typology, Sivas}

\section{Giriş}

Kültürel miras ve koruma kavramları önemli anıtsal yapıların fiziksel bütünlüklerinin korunmasıyla ortaya çıkmış, çevre ve kent ölçeğinde korumaya kadar gelişmiştir. Geçtiğimiz yüzyılın sonlarından itibaren ise bu kültürel miraslar somut olmayan yanları ile de ele alınmaya başlanmıştır. Koruma kavramının gelişmesinde önemli bir adım olan Venedik Tüzüğü (1964), korunması gerekli kültür mirası kapsamını "Tarihi anıt kavramı sadece bir mimari eseri içine almaz, bunun yanında belli bir uygarlığın, önemli bir gelişmenin, tarihi bir olayın tanıklığını yapan kentsel ya da kırsal bir yerleşmeyi de kapsar. Bu kavram yalnız büyük sanat eserlerini değil, ayrıca zamanla kültürel anlam kazanmış daha basit eserleri de kapsar." şeklinde belirtmiştir. Geleneksel konutların koruma literatüründe ilk olarak bu madde kapsamına girdiğini söylemek mümkündür. Venedik Tüzüğü'nü tamamlamak üzere hazırlanan 'Washington Tarihi Kentlerin ve Kentsel Alanların Korunması Tüzüğü (ICOMOS, 1987)' 'tarihi kent ve bölgelerdeki özel ve kamusal yaşam alanları arasında uyum sağlamayı ve bu alanlarda mütevazı boyutlarda da olsa, var olan ve insanlığın belleğini oluşturan kültürel değerlerin korunmasını desteklemeyi" hedeflemiş, böylelikle koruma kavramının kapsamı gelişmiş ve koruma kentsel çevrelerle birlikte ele alınmaya başlanmıştır. Bununla birlikte geçmişteki sosyal yaşamın belgeleri niteliğindeki geleneksel konutlar da koruma literatürü kapsamına girmiştir. ICOMOS'un Ekim 1999'da Meksika'da kabul edilen Geleneksel Mimari Miras Tüzüğü'nde geleneksel mimari mirasın ayırt edici özellikleri: "toplumca paylaşılan bir yapı geleneği; çevreye uygun yöresel veya bölgesel bir kimlik; üslup, biçim ve görünüş tutarlıı̆̆ı, veya geleneksel yapı türlerine bağlıık; anonim olarak aktarılan geleneksel tasarım ve yapı ustalığı; işlevsel, sosyal ve çevresel kısıtlamalara etkin olarak cevap verebilme; geleneksel yapım sistemlerinin ve zanaatlarının etkin uygulaması" olarak sıralanmıştır (ICOMOS: 1999). Bu tüzük ile geleneksel mimari miras ile ilgili kriterler belirlenmiştir. Türkiye'de ise Dünya'da yükselen korumadaki gelişmeleri yakalamaya yönelik 1960'lı yıllarda hızlanan çalışmaların ardından 1973 yılında çıkarılan "1710 sayılı Eski Eserler" kanunu ile koruma, çevre ve doku ölçeğinde ele alınmıştır. Kapsamı genişleyen koruma anlayışıyla birlikte Anadolu'da geleneksel konutların miras olarak tespit ve değerlendirilmesi bu tarihlerde başlayarak ivmelenmiştir.

Anadolu'nun bugünkü toprakları hem coğrafi hem de kültürel olarak heterojen bir oluşum sergilemektedir. Orta Anadolu'ya hâkim kerpiç yapı kültürü, Güneydoğu ve Mezopotamya bölgesindeki taş yapı dokusu, Ege ve Akdeniz bölgesinde görülen kübik ve renkli yapılar bu çeşitliliğin göstergesidir. Çok kültürlüğün ve coğrafi çeşitliliğin getirdiği bu zenginlik içerisinde, Osmanlı İmparatorluğu'nun hakimiyeti esnasında Orta Anadolu'dan Balkanlara kadar uzanan geniş bir alana yayılmış ve 400 yıl boyunca gelişmiş, temel ögeleri ve oranlarıyla yaygın bir konut tipolojisinden bahsetmek 
mümkündür. Yapısal olarak karmaşık bu konut taş, kerpiç ve ahşabın bir arada kullanımından meydana gelmektedir (Kuban, 1995, s.16). İç Anadolu'nun doğusunda yer alan Sivas ilindeki geleneksel konut uygulamaları bu yaygın konut tipi ile örtüşmektedir.

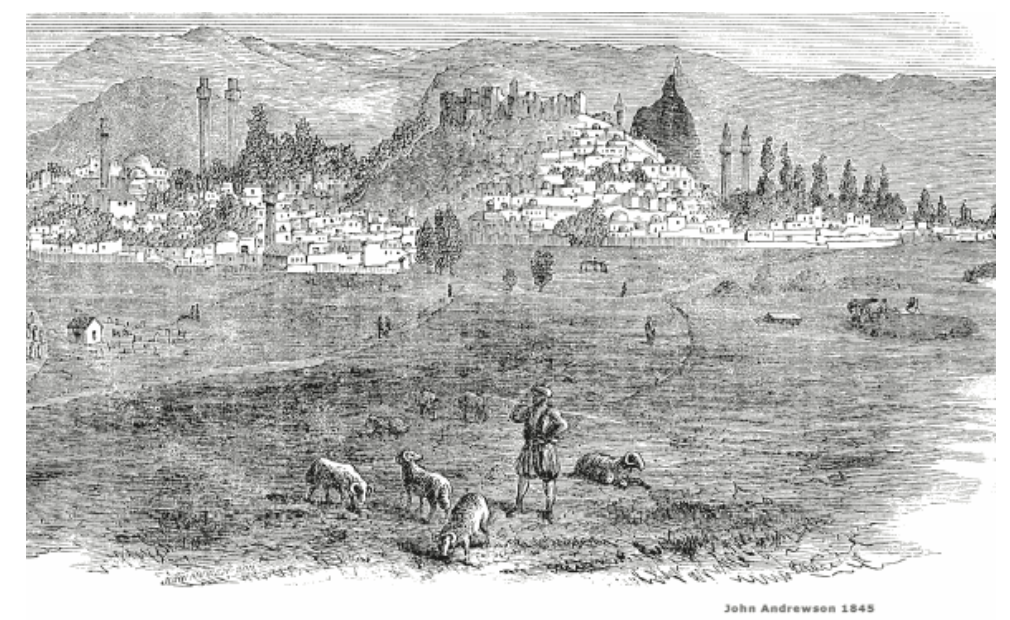

Şekil 1: 1845 Yılında Sivas Kenti (John Andrewson, URL 1)

Sivas kenti, Roma ve Orta Çağ'da kale olarak kullanılmış, doğal bir kaya tepelik olan (URL 2) ${ }^{3}$ Topraktepe (Sivas Kalesi) etrafında gelişmiştir (Şekil 1). Şehrin yerleşimine dair en önemli kaynaklardan biri Gabriel'e aittir (Şekil 2). Görselden şehrin surlarla korunduğu ve kapılarla giriş çıkışların sağlandığı okunabilmektedir. Stratejik öneme sahip olması sebebiyle savunması şehrin morfolojisini oluşturan temel etken olmuştur. Mevcut kale olan Topraktepe "Yukarı Kale" olarak anılmakta olup ilk kale olan "Aşağı Kale" bugüne ulaşamamıştır. Aşağı Kale'nin bugünkü konumu Şifaiye Medresesi, Buruciye Medresesi, Çifte Minare Medresesi, Kale Camii ve Kale Hamamı kalıntısının yer aldığı bölgedir (Uzunçarşıı, 2014, s. 12-31). Mahalleye de ismini veren kale (Eski Kale Mahallesi) yüzyıllardan bu yana kentin hafızasında varlığını sürdürmektedir.

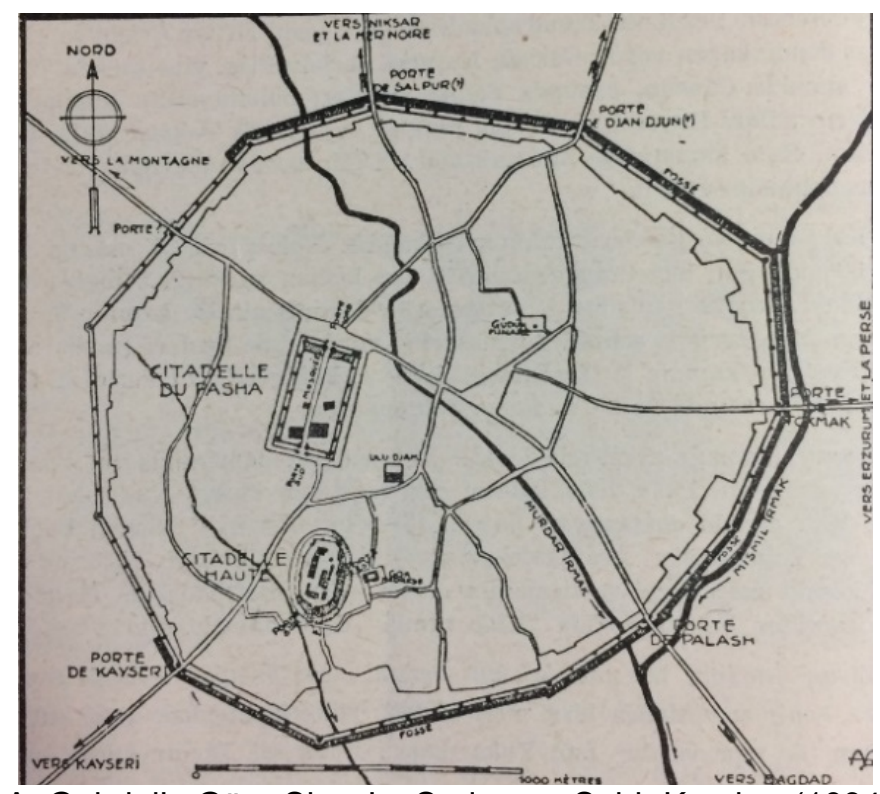

Şekil 2: A. Gabriel'e Göre Sivas'ın Surları ve Şehir Kapıları (1934, s. 135)

\footnotetext{
${ }^{3}$ Sivas Kültür Envanteri https://www.sivaskulturenvanteri.com/sivas-kalesi-topraktepe/ (URL 2)
} 
Şehrin yerleşimine beşerî etkenlerin yanı sıra coğrafi etkenler de yön vermiştir. Kızılırmak nehri, yağışın yoğun olduğu bahar aylarında taşkınlara sebep olduğundan yerleşim Güney yönünde gelişmemiş, yapılan ıslah çalışmalarıyla nehrin kontrol altına alınmasının ardından şehir bu yönde genişlemeye başlamıştır (Bilget, 1993, s.45). Yerleşimine Mısmılırmak, Murdar Irmak ve Pünzürük derelerinin de yön verdiği şehirde ikamet ve ticaret alanları ayrı bölgelerde konumlanmış ancak zamanla bölgeler arasındaki sınır kalkarak birleşmiştir (Bilget, 1993, s.45).

Tarihi yapılar; mimari üslupları, yapım teknikleri ve yapı malzemeleriyle bulunduğu coğrafyaya ve ait olduğu kültüre dair yüzyıllardır bünyesinde biriktirdiği pek çok bilgiyi saklamaktadır. Sivas geleneksel konutları Orta Anadolu bölgesi geleneksel konut tipolojisiyle örtüşmektedir. 1839 yılında Moltke ve 1880'li yıllarda Cuinet'nin Sivas'ı ziyaretleri esnasında kaydettikleri gözlem notlarına göre bu dönemde şehir toprak damlı kerpiç evlerden oluşmaktadır (Mahiroğlu, 1993, s. 14-20; Akbulut, 2009, s. 213). 19. yüzyılın sonlarına doğru batılılaşma hareketlerinin etkisiyle vilayet yönetimince toprak damlı evlerin yapımı yasaklanmış, şehrin yeni dokusunu kiremit kaplı çatılar oluşturmaya başlamıştır (Akbulut, 2009, s.213). 19. yüzyılın sonları ve 20. yüzyılın başlarında; Sivas'ın siluetini ahşap, taş ve kiremit malzemelerin harmanlandığı haçvari ve köşklü karakteristik evler oluşturmaktadır (Şekil 3). Özellikle büyük konakların harem-selamlık plan şeması, ev-avlu-sokak düzeninin işleve uygun tasarlanarak bütünlük oluşturması, o günün kültürü ve yaşam koşullarıyla bütünleşmiştir.

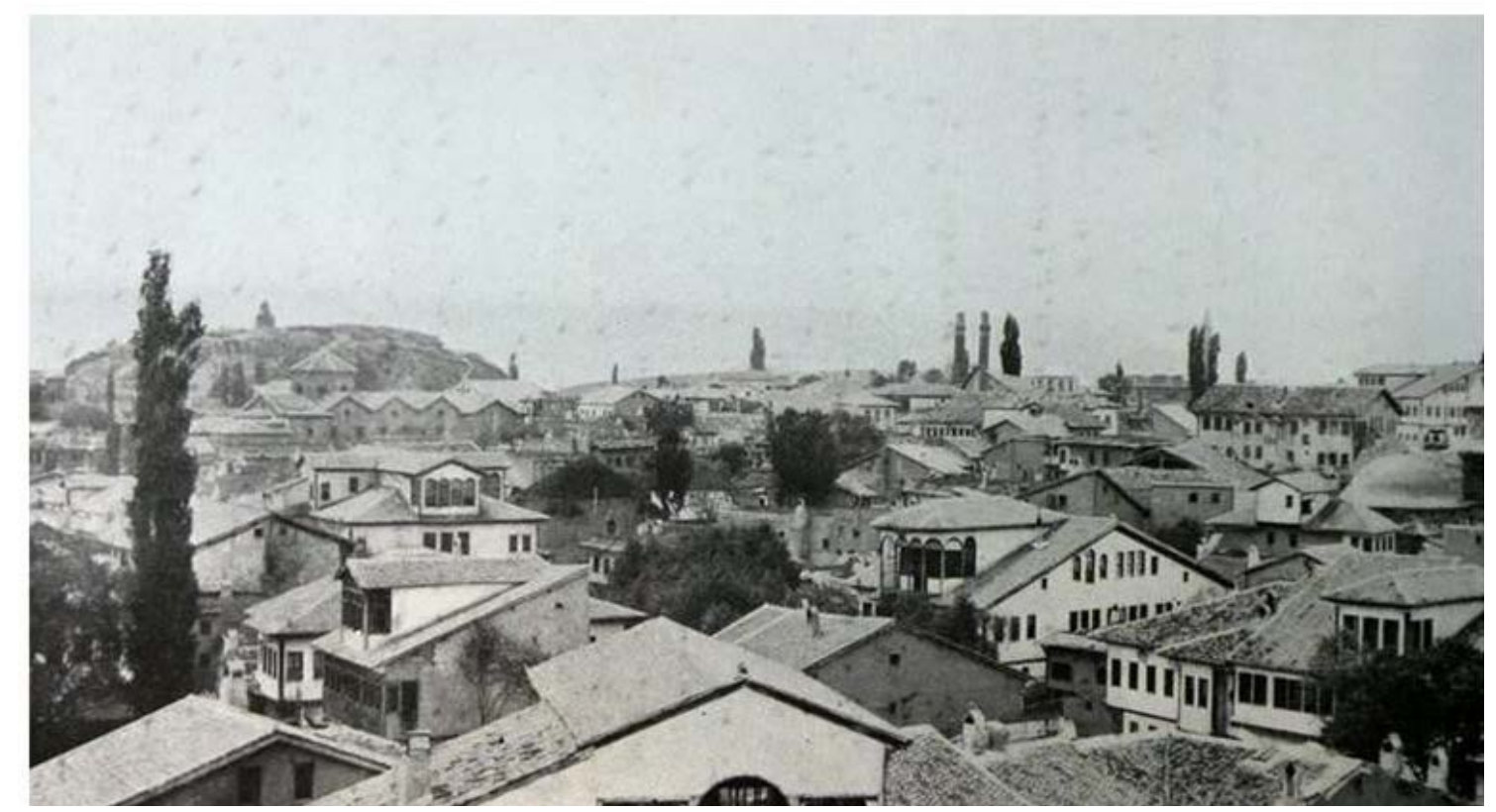

Şekil 3: 20. Yüzyıl başları sivas kent dokusu (Anonim, URL 3)

Sivas bünyesinde barındırdığı medreseleri, camileri, hanları, hamamları, hükümet konağı ve sivil mimari örnekleri ile geleneksel bir Anadolu kentinin izlerini bugüne taşımıştır. Anıtsal yapılar Hükümet Konağı'nın yapılmasının ardından "Sarayın Önü" olarak anılan bugünkü kent meydanı etrafında konumlanmaktadır. Kentin konut dokusu, meydanı odak noktası alarak ışınsal bir yerleşim göstermiştir. Eski fotoğraflarda konutların tarihi meydanda yer alan medreselerin duvarlarına kadar yanaştığı görülmektedir. Bu yoğun konut dokusu, anıtsal eserleri ortaya çıkarmak ve zarar görmelerini engellemek maksadıyla zamanla yıkılmıştır. Günümüzde şehirde bu konutlara ait mahalle ölçeğinde bir dokudan söz edilememektedir. Geleneksel konutlar 
mevcut durumda, şehrin eski mahallelerinden olan Akdeğirmen, Gökçebostan, Bahtiyarbostan, Çarşıbaşı ve Çayyurt mahallelerinin bir bölümünde yoğunlaşmaktadır.

Çalışmada yok olmaya yüz tutmuş olan geleneksel Sivas evlerinin mevcut örneklerinin belgelenmesi, mimari özelliklerinin değerlendirilmesi ve koruma sorunlarının ortaya konması amaçlanmıştır. Kent genelinde yapılan tespit çalışmaları neticesinde günümüze ulaşabilen geleneksel konut örneklerinin tek bir mahalle, bölge ya da sokakta süreklilik oluşturmadığı, şehrin çeşitli noktalarında dağınık olarak yer aldığı görülmüştür. Bu bağlamda çalışma alanı sınırları belirlenirken Tarihi Kent Meydanı merkez kabul edilerek ulaşılabilen en son geleneksel konutların bulunduğu mahalleler olan Halil Rıfat Paşa, Kaleardı, Gökmedrese, Yahyabey, Pulur, Demircilerardı, Küçükminare, Ferhatbostan, Mısmılırmak, Alibaba, Akdeğirmen, Yüceyurt ve Örtülüpınar mahalleleri sınır kabul edilmiş, bu mahalleler ve aralarında kalan kent parçası çalışma alanını oluşturmuştur (Şekil 5). Alan çalışması esnasında Sivas Kalesi eteğinde yer alan III. Derece arkeolojik sit alanı bölgesinde, 'Sivas Kale Projesi' kapsamında inşa faaliyetleri devam etmekte olduğundan alanın bir kısmında tespit yapılamamış bu sebeple söz konusu alan, çalışma alanı dışında kabul edilmiştir.

Çalışma alanındaki tüm sokaklar tek tek taranmış ve 106 geleneksel konut tespit edilmiştir. Tespit edilen geleneksel konutların 106'sında dış tespit, 35'inde iç tespit yapılmış, yapıların cephe ve plan organizasyonları, yapım sistemi ve malzeme kullanım özellikleri incelenerek analiz edilmiş, koruma sorunları belirlenerek çalışma kapsamında sunulmuştur.

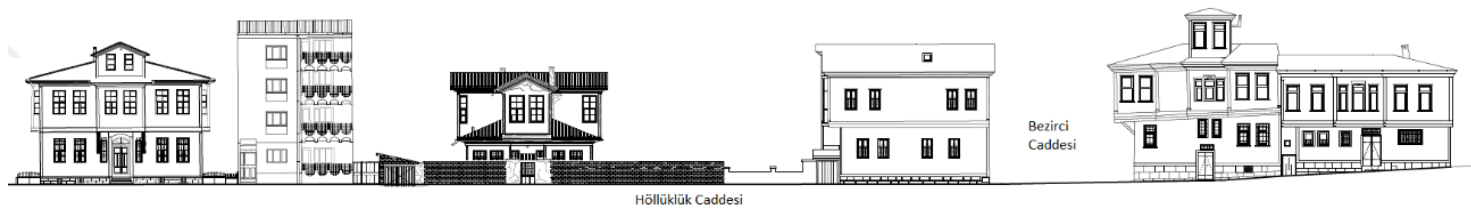

Şekil 4: Sivas'ta geleneksel konutların yoğunlaştığı höllüklük caddesi silüeti (2017) 


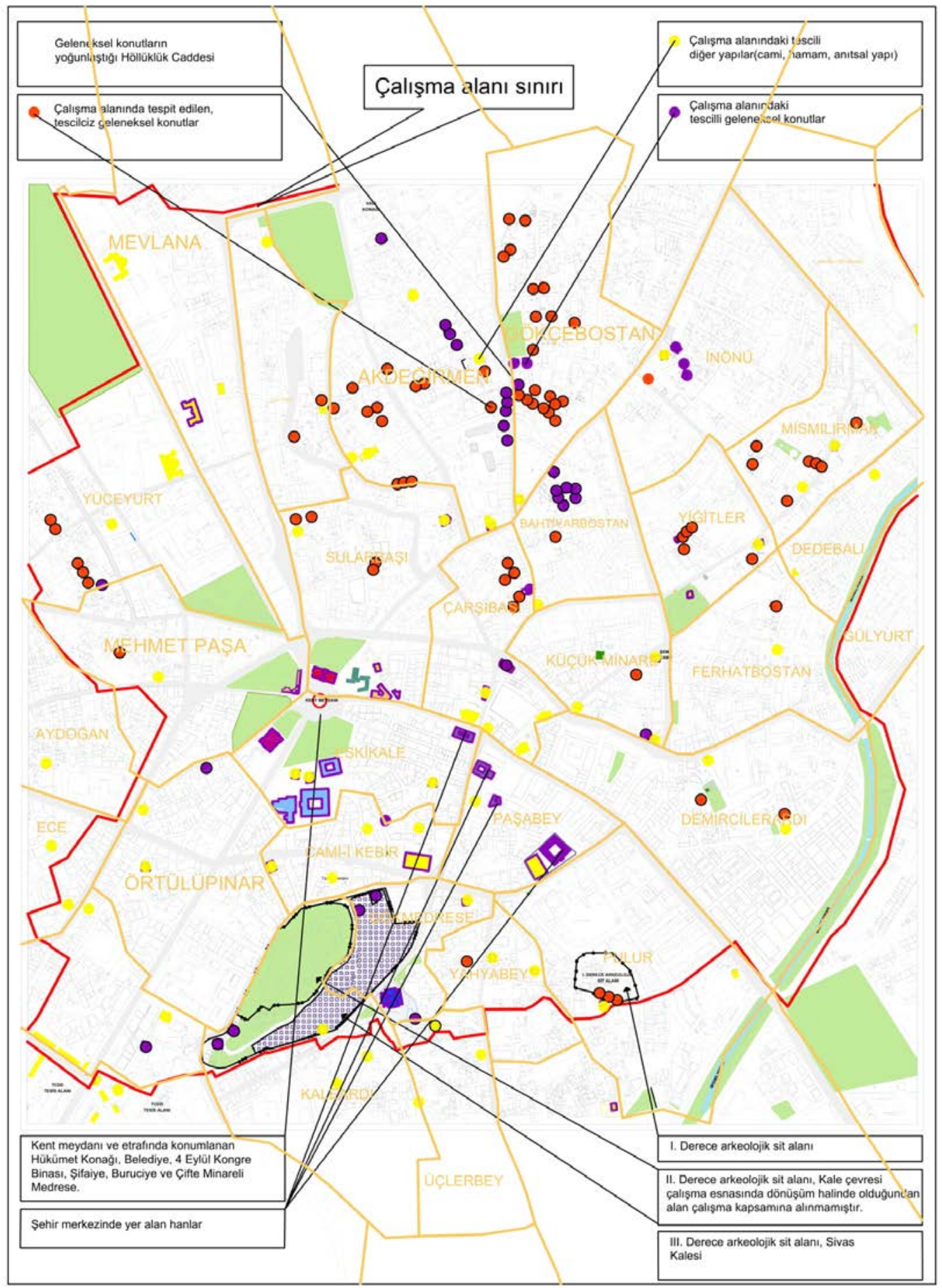

Şekil 5: Sivas'ta geleneksel konutların kentte dağılımı ve çalışma alanı

\section{Araştırmanın Yöntemi}

Çalışmalara literatür taramasıyla başlanmıştır. Bu kapsamda Sivas il yıllıkları, ilgili kitap ve bilimsel araştırmalar taranmıştır. Geleneksel konutların mülkiyetleri farklı kişi ve kurumlara ait olduğundan Sivas Belediyesi, Sivas Kültür ve Tabiat Varlıklarını Koruma Bölge Kurulu, Sivas İl Kültür ve Turizm Müdürlüğü ve Sivas Vakıflar Bölge Müdürlükleri ile görüşülerek arşiv çalışmaları yapılmıştır. Geleneksel konutların korunmasıyla ilgili 
süreçlerin seyrini incelemek amacıyla Kültür ve Turizm Bakanlığı Kültür Varlıkları ve Müzeler Genel Müdürlüğü'nün ilgili ilke kararları incelenmiştir.

Alan çalışması üç aşamalı yürütülmüştür. Birinci aşamada geleneksel konutların yerleşim dokusunu incelemek ve çalışma alanının sınırlarını çizebilmek amacıyla şehirde ulaşılabilen bütün geleneksel konutlar tespit edilmiştir. İkinci aşamada tespit edilen geleneksel konutlar numaralandırılarak envanter çalışması gerçekleştirilmiştir. Üçüncü aşama olarak elde edilen veriler bilgisayar ortamına aktarılarak analizleri ve değerlendirilmeleri yapılmıştır.

Alandaki fiziksel tespitlerin yanı sıra aktif kullanıcısı olan konutlarda, kullanıcılarla bire bir görüşme yöntemiyle sosyal anket yapılmıştır. Anketin temel amacı kullanıcıların koruma bilinç düzeyini ölçebilmek ve yapıya verdiği değerin kullanıcı profili ile ilişkisini ortaya çıkarmak olmuştur. Bu kapsamda "Tarihi çevre koruma nedir? Tescil nedir? Kullandığınız yapının sizce korunmaya değer özellikleri nelerdir? Sizce bu yapı korunmaya değer mi? gibi açık uçlu sorular yöneltilmiştir.

\section{Bulgular}

\subsection{Sivas geleneksel konutlarının mimari özellikleri}

Geleneksel konutlar büyük ya da küçük bir bahçe içerisinde genellikle ayrık nizamda konumlanmıştır. Özgün bahçe duvarları mahremiyeti sağlamak amacıyla iki metreyi aşan yüksekliktedir. Ancak restore edilmiş konutların bahçe duvarları konutun sergilenmesi arzusuyla 50-100 cm arası yükseklikte yeniden yapılmıştır.

Bahçe içinden konuta ulaşılan çift kanatlı kapı sofaya açılmaktadır. Ev yaşamı, sofanın etrafında şekillenmiştir. Katlar arasında işlevsel farklılık vardır. Kış mevsiminin çetin geçtiği şehirde, ara kat ya da zemin kat ısınmayı kolaylaştırmak için kışlık kullanıma uygun tasarlanmıştır. Bu katta pencere sayıları ya da açıklıkları üst kata göre azaltılmıştır. Yalıtımı sağlamak amacıyla pencereler çift kasa olarak tasarlanmıştır. Mekanlar yazlık kata kıyasla daha küçük metrekarelere bölünerek ısıtılması kolaylaştııımıştır. Mutfak konutun kışlık katında yer aldığından ocak bu katta konumlanmıştır. Örneği az olmakla birlikte kimi konutlarda odalarda münferit ocakların da bulunduğu tespit edilmiştir. Zemin kat, dışarıdan gözün ulaşabileceği bir kot olduğundan, sokağa bakan cephe ya sağırdır ya da pencereler oldukça küçük ebatlarda tutulmuştur (Şekil 6). Bu kat nispeten karanlıktır ve genellikle hizmet birimleri burada konumlanmaktadır. Konutun üst katı sokağa taşan çıkmalarla geniş, aydınlık ve ferah mekanlar sunmakta ve yazlık kat olarak kullanılmaktadır. Bu katta pencereler tek kasa olacak şekilde tasarlanmıştır. Çıkmalarla genişleyen sofa daha geniş ve ferah bir mekâna dönüşmüştür.
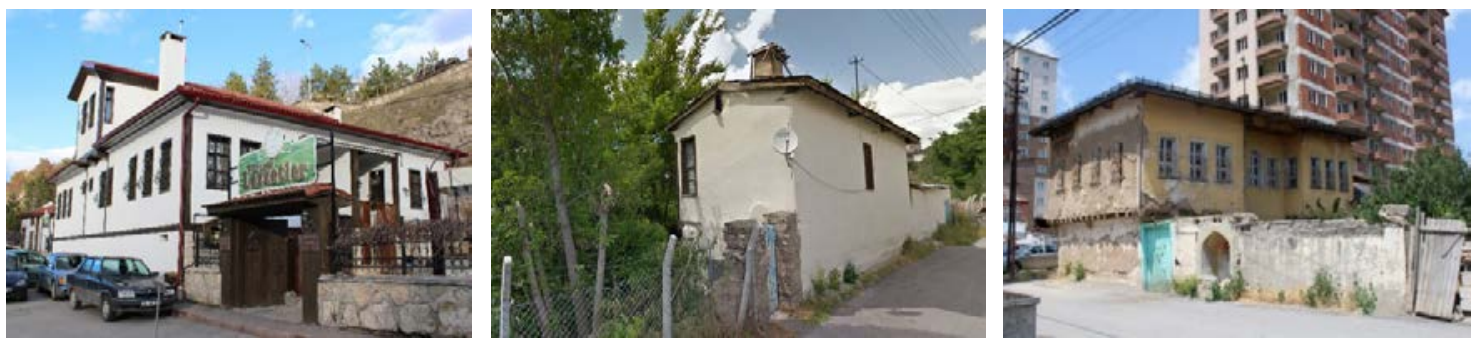

Şekil 6. Sivas geleneksel konutların sokak-cephe ilişkisi (Gülhayat Kılcı) 
Kullanıcının zenginliği, konutun cephesindeki sadeliği bozacak bir etki göstermemiştir. Ailenin zenginliği yapının ölçeğinin büyüklüğünden ve iç mekân süslemelerinden anlaşılmaktadır. Şehrin özgün yerleşiminde geleneksel konutlar genellikle iki ya da üç katlı olup plan şeması harem-selamlıklıdır. Ataerkil aile yapısının çözülerek çekirdek aileye dönüşmesi, bu büyük ölçekli yapılarda kullanım zorluğu oluşturmuş, bunun yanında miras paylaşımından kaynaklı olarak yapıların birçoğu bölünerek iki ayrı ev haline getirilmiştir.

\subsection{Sivas geleneksel konutlarının yerleşim özellikleri}

Geleneksel konutlar özgün koşullarda geniş bahçeler içerisinde konumlanmıştır. Ancak zamanla günümüz konutlarına ilginin artarak geleneksel konutların gözden çıkarılmasıyla, mülkiyet problemi geniş bahçelerin bölünerek arsaya dönüştürülmesine sebep olmuştur. Özgün parsellerde yeni yapılaşmalar oluşması ya da yol açma, yol genişletme gibi çalışmalar sebebiyle konutların açık alanları yok olmuş ya da daralmıştır.

Günümüze ulaşan halleri ile geleneksel konutların konumları ile ilişkisi tespit edilirken konum tipolojisinin; konutun büyüklüğü, plan tipolojisi (tek bölümlü ya da haremselamlıklı) ve sokaktaki yerleşimine göre farklılık gösterdiği görülmüştür. Yapı konumlanışları bahçesiz ve bahçeli olmak üzere ikiye ayrılmaktadır. Bu iki grup altında ise girişlerin bahçeden ya da sokaktan oluşuna, köşe ya da ara parselde konumlanmalarına göre alt tiplere ayrılmaktadır (Şekil 7).

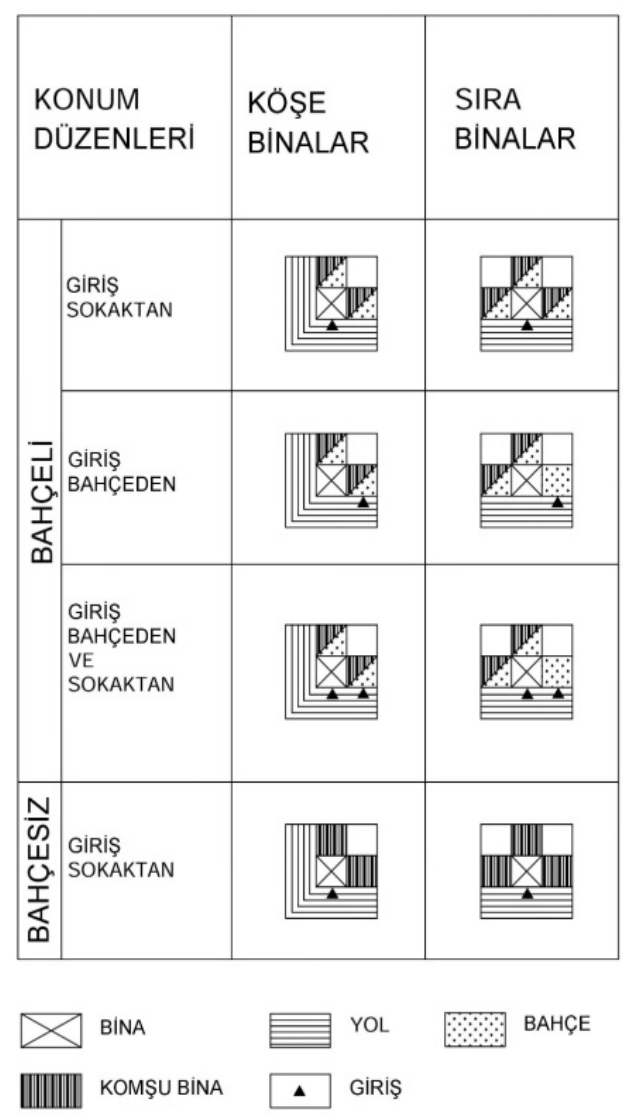

Şekil 7: Sivas geleneksel konutlarında konum tipolojisi (Gülhayat Kılcı) 
Tek bahçeli konutlarda, sokak cephesinde bahçenin bulunduğu ve bahçeden geçilerek konuta ulaşılan ve ya bahçesi arka cephede olup yapının içerisinden geçerek ulaşılan örnekler bulunmaktadır. İki bahçeli konutlarda yola bakan, yabancı gözün daha çok gördüğü ve dışa daha çok hitap edeni bahçe olarak adlandırılırken, yapının arkasında kalan, evin içerisinden geçilerek ulaşılan gözden uzak ikinci bahçe meyve ağaçlarının ve günlük intiyacı karşılayacak sebzelerin yetiştirildiği açık alandır ve bostan olarak adlandırılmaktadır. Konutların bir kısmında yapının sokakla ilişkisini "avlu" sağlamaktadır (Şekil 8). Konutun sokakla ara kesitini oluşturan bu mekân mahremiyet gözetilerek yüksek bahçe duvarıyla dışarıdan bir gözün görmeyeceği şekilde çevrelenmiştir. Avlu ise kış mevsimi hazırlıklarının, günlük işlerin ve mevsimlik temizliklerin yapıldığı yarı açık bir mekandır. Sokakla ilişkisi genellikle çift kanatı bir kapıyla sağlanır. Sokağa açılan bahçe kapısı ile konutun giriş kapısı arasındaki zemin taşla kaplanmıştır.

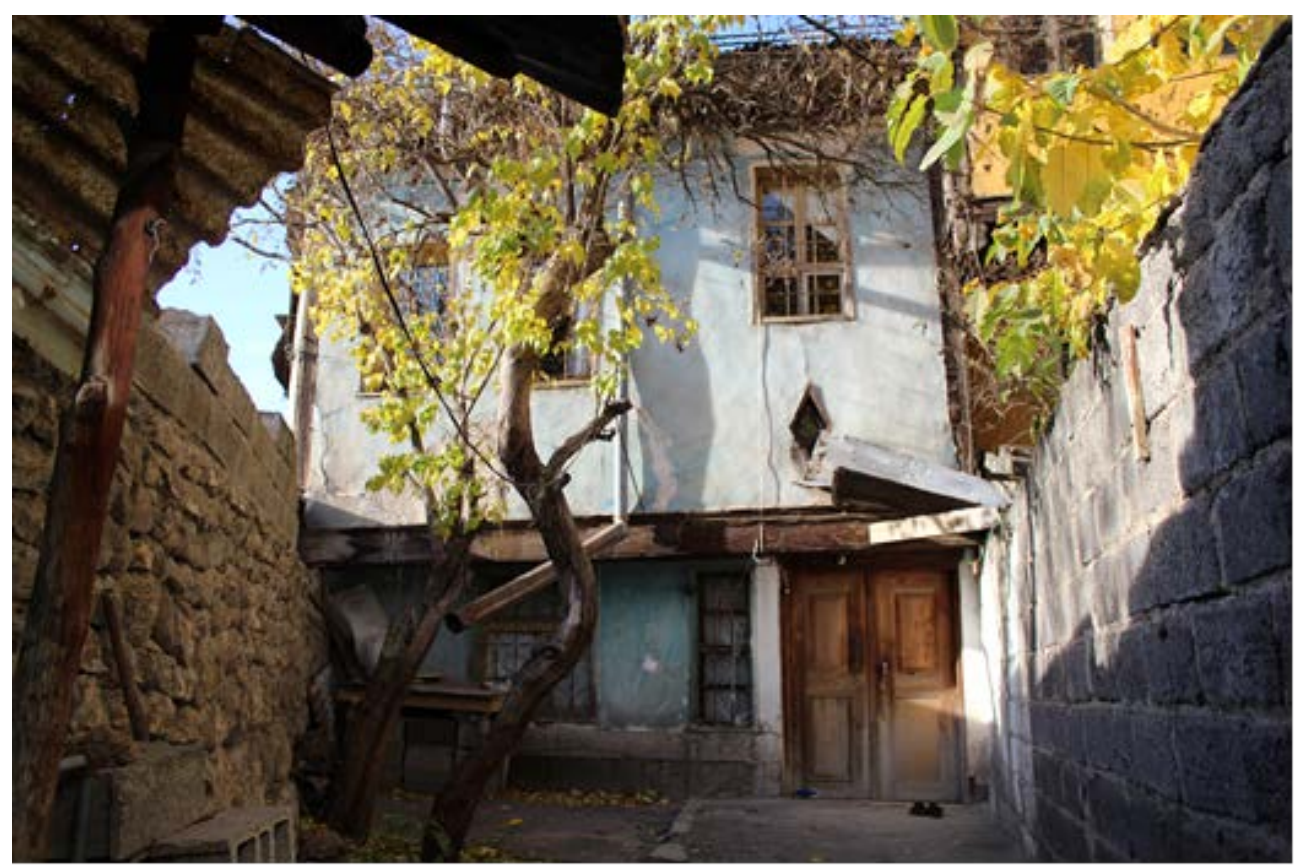

Şekil 8: Sivas geleneksel konutları-avlu örneği (Gülhayat Kılcı)

\subsection{Sivas geleneksel konutlarının plan özellikleri}

Çalışma kapsamında incelenen 106 geleneksel konuttan 35'inin iç mekânına ulaşılarak analiz yapılmıştır. Plan organizasyonu açısından konutlar, tek bölümlü ve iki bölümlü (harem-selamlıkı) olarak ikiye ayrılmaktadır. Çok katlı konutların zemin katı servis ihtiyacına hizmet etmek üzere tasarlanmıştır. Zemin kat planında yapı, sokak çizgisine ve araziye uyum sağlamaktadır. Üst katta, manzaraya açılan çıkmalarla yapının planı dik açılı biçimdedir ve plan alt kata göre daha net okunmaktadır. Bu nedenle plan tipolojisi üst katlar baz alınarak değerlendirilmiştir. Ancak harem selamlıklı plan tipine sahip konutlarda 1. katı cihannümana olanların ana katı zemin kat olduğundan plan tipi zemin kata göre belirlenmiştir.

Yapılan analiz ve değerlendirmeler sonucunda, Sivas geleneksel konutlarının plan tipolojisi; kapalı dış sofalı, köşe sofalı, iç sofalı ve orta sofalı olmak üzere dört ana tipte olduğu belirlenmiştir. İç sofalı planlar: tek yüzlü ve ikiyüzlü, orta sofalı planlar: iki ve dört eyvanlı olarak alt gruplara ayrılmıştır. Değerlendirme sonucunda plan tiplerinin birer örneği çizelgede verilmiştir (Şekil 9). 


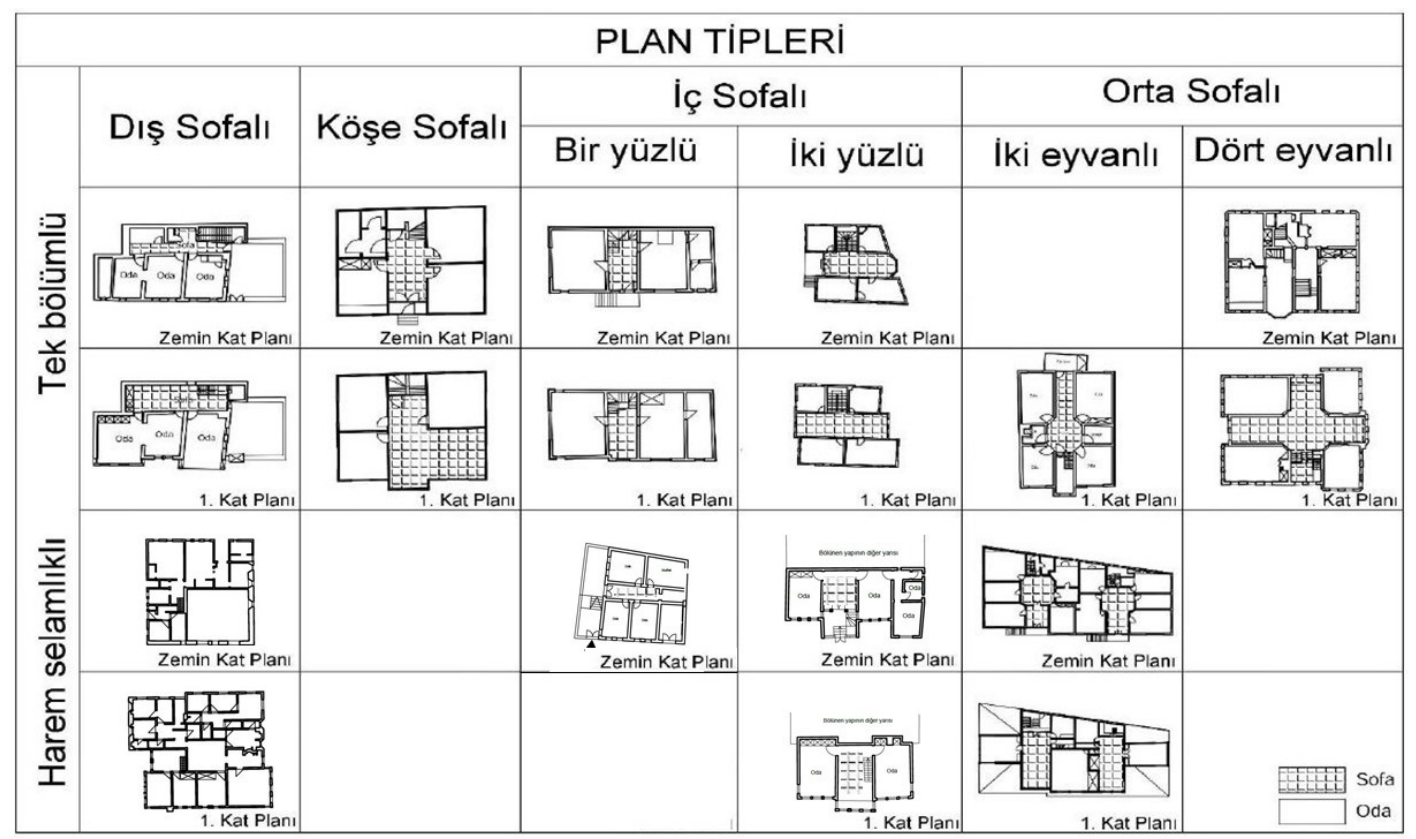

Şekil 9. Sivas geleneksel konutları plan tipolojisi (Gülhayat Kılcı)

Türk evinin en eski plan tipi olarak yorumlanan dış sofalı plan şeması, iklim koşullarının sert olması sebebiyle Sivas geleneksel konutlarında kapalı tipte görülmektedir. Analizi yapılan 35 konuttan 2'sinde kapalı dış sofalı plan tipi tespit edilmiştir. Dış sofalı plan tipinin bir alt birimi olan köşe sofalı plan şeması 8 adet konutta tespit edilmiştir. Çalışma alanında mevcut plan tipleri arasında en sık rastlanan tip iç sofalı plan tipidir. İki tarafında odalar bulunan dikdörtgen planlı sofanın, iki yüzü ya da bir yüzünün dış mekanla ilişki kurmasına göre, bir yüzlü iç sofalı ve iki yüzlü iç sofalı olarak iki ayrı plan tipi tespit edilmiştir. Sofaların biçimlenişi, manzara, komşu yapılarla kurulan ilişkiler ve iklim koşulları sebebiyle açıklığı en aza indirme eğilimlerinden etkilenmiştir. 35 konuttan 17 'si bir yüzlü iç sofalı plan şemasına, 5'i iki yüzlü iç sofalı plan şemasına sahiptir. Gelişmiş bir plan şeması olan orta sofalı plan tipinde sofa, evin ortasında yer almakta, dört yanında odalar ve eyvanlar bulunmaktadır. Aydınlık ve ferah bir plan şeması olan bu tipe ait çalışma alanında günümüze ulaşan iki eyvanlı 2 örnek, dört eyvanlı 1 örnek tespit edilmiştir. Yaşam kültürünün Türk evlerine yansımış en tipik mimari davranışlarından biri olan harem-selamlıklı evlerden günümüze 7 örnek ulaşmıştır. Bunlar, bir yüzlü iç sofalı (2 yapı), iki yüzlü iç sofalı (1 yapı), iki eyvanlı orta sofalı (2 yapı) ve dış sofalı (2 yapı) plan tiplerindedir.

\subsection{Sivas geleneksel konutlarının cephe özellikleri}

Geleneksel Sivas konutlarının cephe organizasyonları oldukça yalın bir biçimleniş sergilemektedir. Bölgede hâkim olan ahşap karkas yapım sisteminin elverdiği ölçülerde, cephelere hareket kazandıracak çeşitli biçimlenişler denenmiştir. Türk evinin planlamasında etkili olan mahremiyet intiyacı, konutlarda içe kapalı oluşumla kendini göstermektedir. Bu durum, alt katlarda sağır olan cepheler ya da küçük boyutlu pencereler olarak kendini göstermiştir.

Yapıların üst katında sokağa ya da manzaraya yönlendirilen çıkmalarla cepheler hareketli olarak biçimlenmiştir (Şekil 10). Konutların plan kurguları cephe oluşumunda etkili olan önemli bir etkendir. Konutun çekirdeği olan sofa veya en çok kullanılan odası, çıkmalarla dış mekânla ilişkiyi kuvvetlendirmektedir. Plan ve cephe ilişkileri bağlamında 
Sivas geleneksel konutlarının cephe biçimlenişleri incelenmiş ve ortak özellikleri dikkate alınarak ana cephelerine göre tipolojik çözümleme yapılmıştır. Çıkmaları geometrik biçimlerine göre: dikdörtgen çıkma, çokgen çıkma, testere çıkma, yarım daire çıkma; yapılış biçimlerine göre: açık çıkma, kapalı çıkma; yapının cephesinde konumlanışlarına göre: tüm kat çıkma, ortada çıkma, tek yan çıkma iki yanda çıkma ve köşe çıkma olarak sınıflandırmak mümkündür (Şekil 11).

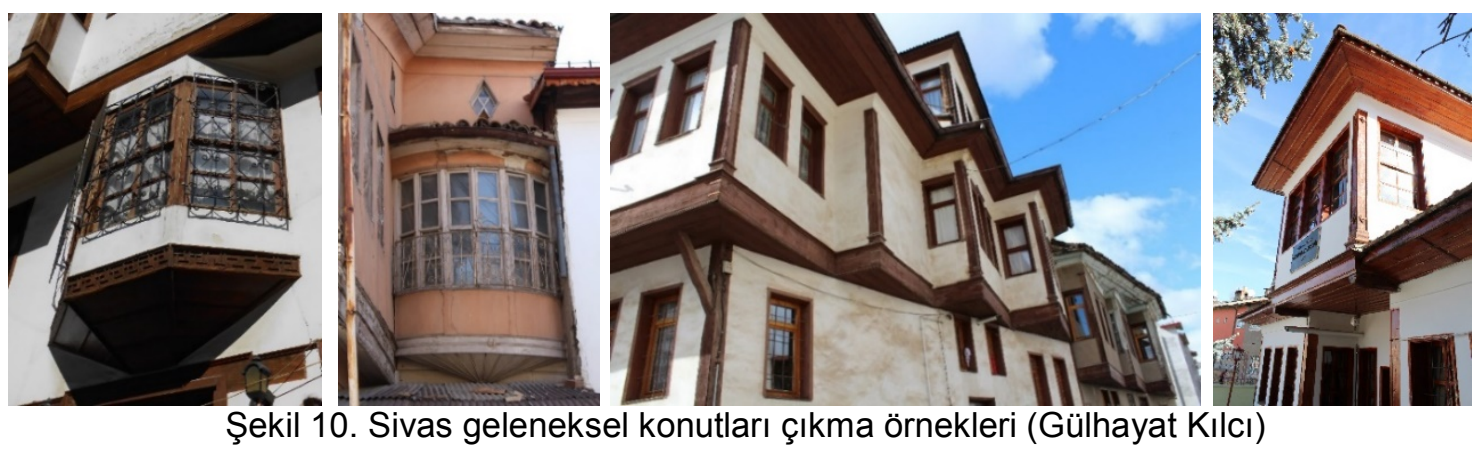

Sivas konutlarının cephe organizasyonunda öne çıkan bir diğer biçimleniş ise köşktür. Özelleşmiş bir mekân olan köşk bir kat olarak ya da tavan arasının değerlendirilmesiyle konutun diğer katlarından ayrılarak özelleşmiş bir kattır. Hem manzarayla hem de sokakla kurduğu kuvvetli ilişki plan ve cepheyi zenginleştirerek anıtsal bir görüntü oluşturmuş, Sivas geleneksel konutlarının karakteristik bir öğesidir.

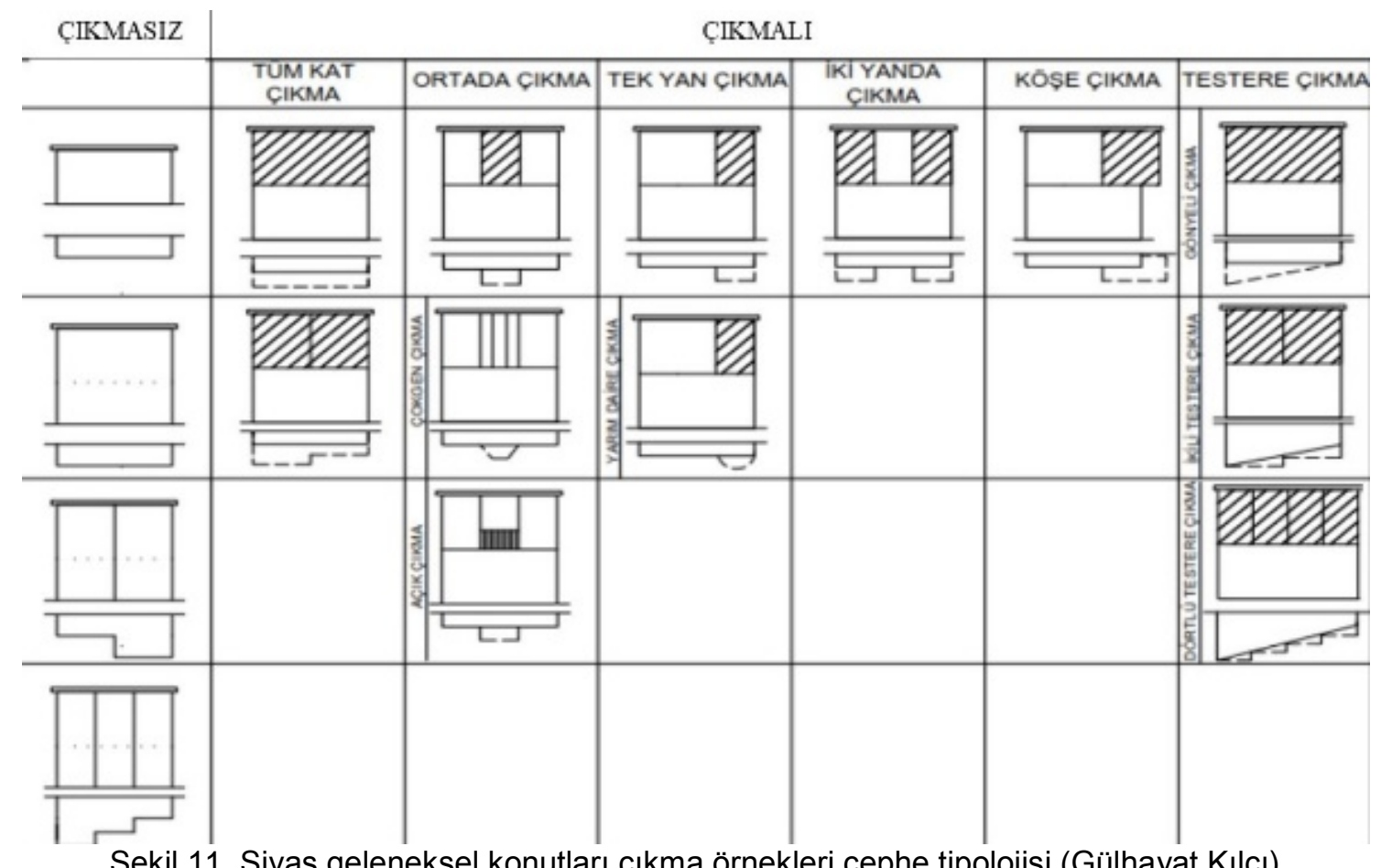

Cephelerde kütlesel olarak kuvvetli bir hareketlilik görülürken, süsleme oldukça yalındır. Kapı, pencere, payanda ve silme gibi ince yapı elemanları cephe estetiğine katkıda bulunmaktadır. Bu elemanlardan pencereler çeşitlilik oluşturur. Açılış biçimlerine göre giyotin ve kanatlı olarak iki tip pencere görülmektedir. En sık rastlanan pencere: dikdörtgen biçimli, yatay yönde 2 birim, düşeyde ise 3 ya da 4 birim bölüntüden oluşan, boyutları farklılık gösteren tiptir. Bu pencerelerde tüm kanat açılan 
ya da yarısı, üçte biri veya dörtte biri sabit olan tipler tespit edilmiştir. Pencerelerde, sert iklim şartlarında soğuktan korunmak için çift kasa kullanılmıştır. Çift kasa pencerelerde korkuluk demiri iç ve dış kasa arasına yerleştirilmiş, dış kasa sökülüp takılabilir şekilde tasarlanmıştır ve mevsimlik kullanıma elvermektedir (Şekil 12). Bu tip, evin kışlık olarak kullanılan ara kattaki mekanların pencerelerinde uygulanmıştır. Açıklığı değiştirilmiş, özgün boyutlara uymayan pencereler de tespit edilmiştir.
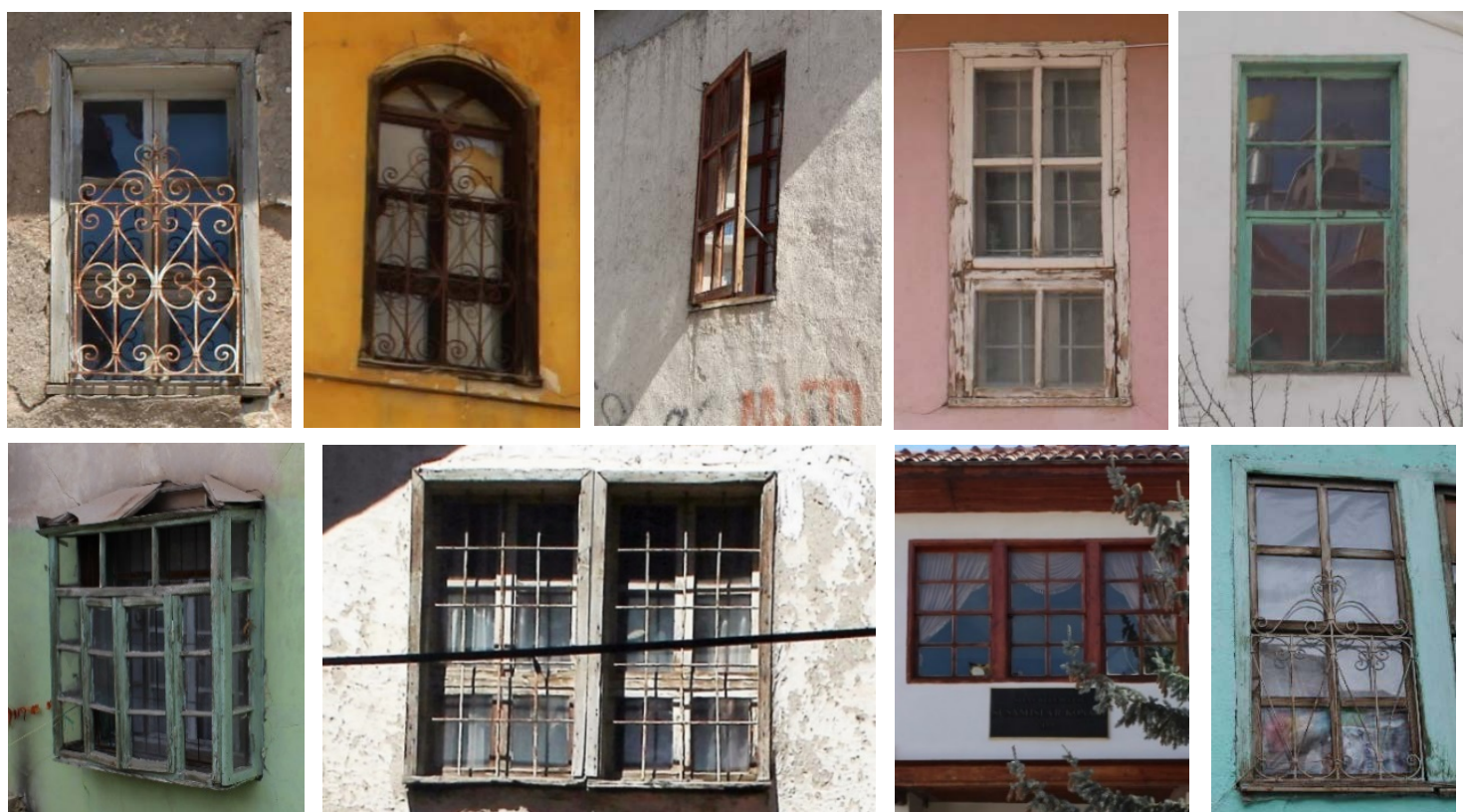

Şekil 12. Sivas geleneksel konutlarından pencere tipi örnekleri (Gülhayat Kılcı)

Konutların giriş kapıları ahşap plakaların kuşaklanmasıyla oluşturulmuş, çift kanatlı basit iş̧̧ilikli ve sadedir. Yuvarlak başlı dövme çiviler kapılarda hem birleştirme hem de süsleme elemanı olarak kullanılmıştır. Kapı genişlikleri ortalama $1.50 \mathrm{~m}$, yükseklikleri 2.20 ile $2.50 \mathrm{~m}$ arasındadır. Bu kapılar, boyutları farklılaşan tepe pencereleri ya da iki yanında bulunan pencerelerle bütünlük oluşturmuştur. Kerpiç ya da taş bahçe duvarlarının devamı olarak sokaktan bahçe ya da avluya girişi sağlayan bahçe kapıları da aynı sadelikle ahşap malzeme kullanılarak yapılmıştır. Kapıların boyutları konutun büyüklüğüne göre farklılık göstermektedir. Bahçe kapısının ardından 3-4 basamak inilerek ulaşılan bahçeler yol kotundan aşağıda yer almaktadır (Şekil 13). 

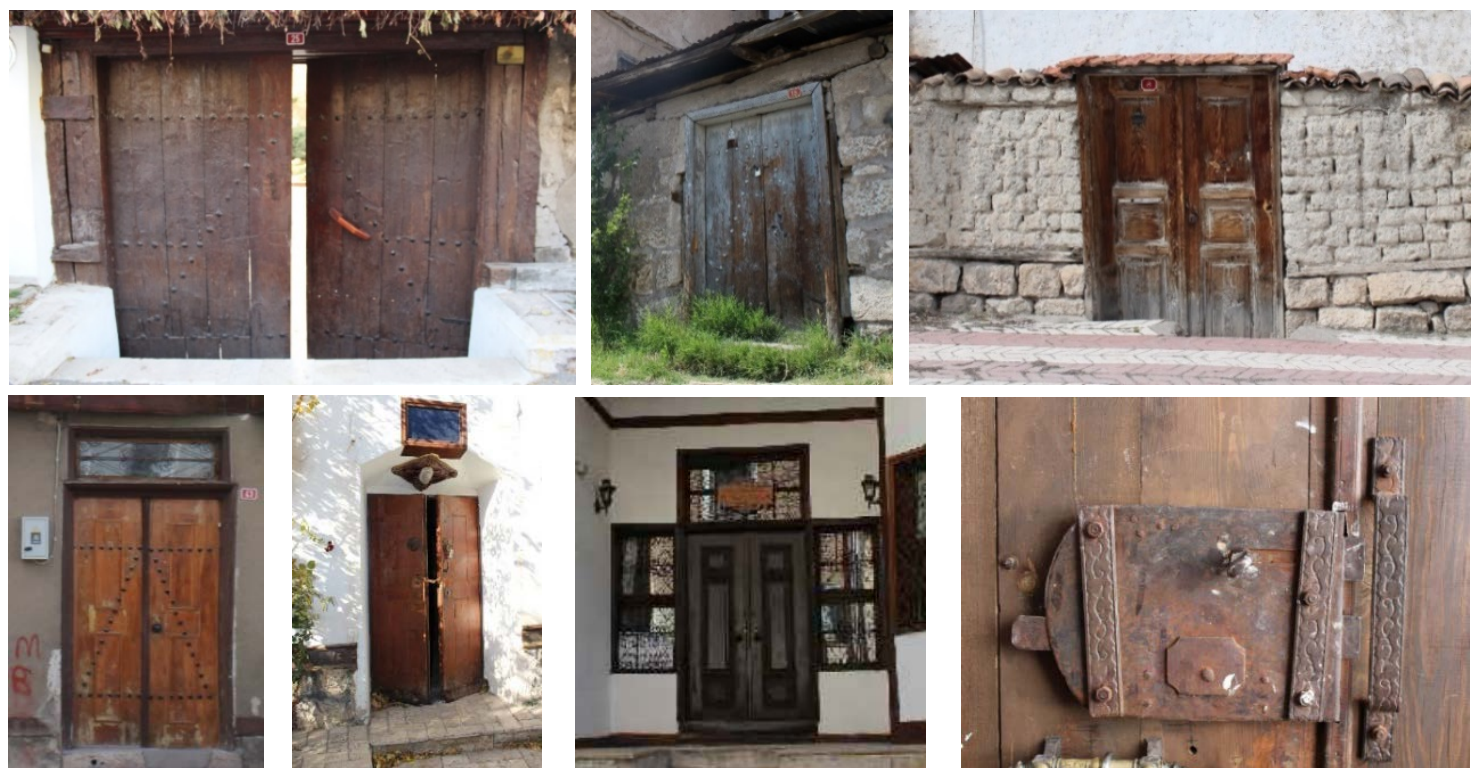

Şekil 13. Sivas konutlarında bahçe kapısı (üstte) ve konut giriş kapısı (altta) örnekleri (Gülhayat Kılcl)

\subsection{Sivas geleneksel konutlarının yapım sistemi ve malzeme özellikleri}

Orta Anadolu'da yaygın olarak uygulanmış kerpiç yapı geleneği Ortadoğu'nun pek çok bölgesinde görülen, kökleri Neolitik döneme dayanan, binlerce yıllık bir yapım sistemi geleneğidir. Geleneksel Türk Evi'nde en sık uygulanan bu yapım sisteminde ev, karmaşık bir yapıdadır. Kerpicin taş ve ahşap malzeme ile bir arada kullanımı yüzyıllarca gelişerek değişmeden devam etmiştir. Temel ve zemin kat yığma taş, üst katlar ahşap karkas arası kerpiç dolgudur. (Kuban, D. 1995, s.16).

Sivas, İç Anadolu Bölgesi'nin doğusunda iklim ve yapım sistemi açısından geçiş noktasında konumlanmıştır. Bozkır ikliminin hüküm sürdüğü bölge ağaç bakımından zengin olmayan otlak ve ekili arazilerle kaplıdır. Yerleşim yerleri hariç ağaç popülasyonunun oldukça az olması sebebiyle ahşap, konutların taşıyıcı yapısında karkas sistem malzemesi olarak kullanılabilmiştir. (Sözen ve Eruzun, 1992, s. 243245). Çalışma alanında kazı çalışması yapılamamıştır ancak subasman kotuna kadar uzanan taş örgü duvar, temelin de taş örgü olarak devam ettiğini düşündürmektedir. Üredi; Sivas evlerinin temel duvarlarının $75-80 \mathrm{~cm}$ genişlikte örüldüğünü, dikdörtgen biçimde örülen iç ve dış duvarların arasının ise horasan harcı ile doldurulduğunu, temelin köşe taşlarının sağlamlaştırılması adına iki köşede açılan oyuklara yerleştirilen demir lamaların kurşun dökerek sabitlendiğini belirtmektedir (Üredi, 2009, s. 19-48).

Alandaki konutların taşıyıcı sistem kurgusu subasman kotuna kadar uzanan taş duvar üzerine inşa edilen ahşap karkas sistemdir. Bölgede taşlık alanların sınırlı olması sebebiyle daha az oranda taş, çoğunlukla ise kerpiç, dolgu malzemesi olarak kullanılmıştır. Kerpiç ve çamur kullanılarak yapılan doldurma işlemi "Kerpiç Dolması", söngüt taşı ve aralarında tatı kireç kullanılarak yapılan doldurma işlemi "Kireççi Dolması" olarak adlandırılmaktadır (Şekil 14). Alanda kerpiç dolgu uygulamasının en yoğun uygulama olduğu saptanmış ancak tüm konutlarda sıva kaldırma uygulaması yapılamadığından kesin bir sayıya ulaşılamamıştır. Tadilatlar esnasında dolgu malzemesinin tuğla ile değiştirildiği örneklere rastlanmıştır. 

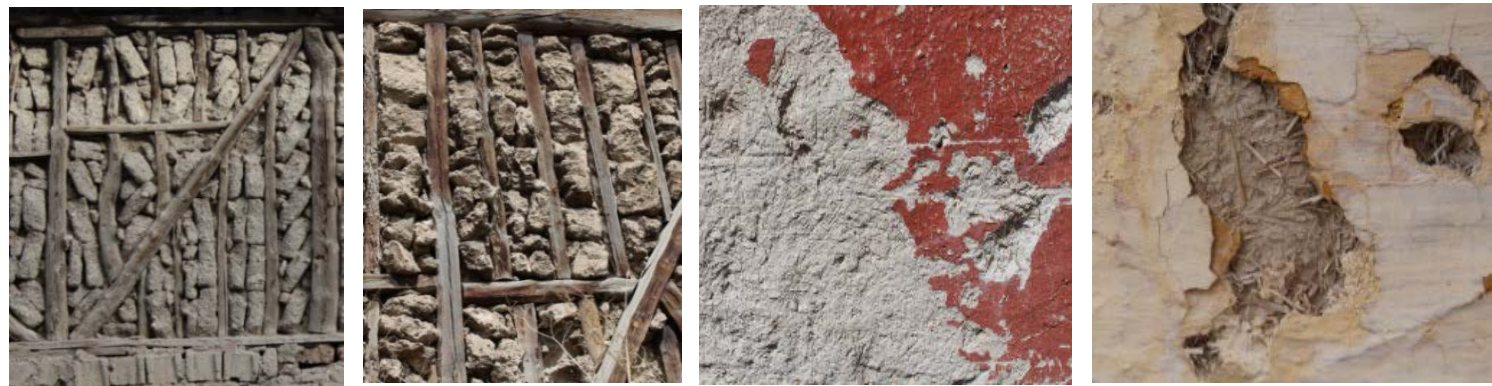

Şekil 14. Sivas konutlarında ahşap karkas dolgu sistemi; sırasıyla: kerpiç dolması, kireçci dolması, sıvalar; tatı kireç sıva, kıtıklı sıva (Gülhayat Kılcı)

Geleneksel konutların özgünlüğü korunmuş olanlarında tatlı kireç sıva ve kıtıklı sıva olarak iki çeşit sıva tespit edilmiştir (Şekil 14). Tatlı kireç sıva civardaki ocaklardan çıkarılan kireç kullanılarak elde edilen bir sıva türüdür. Sıvanın daha pürüzsüz ve parlak görünmesi için ev sahibinin isteği doğrultusunda kimi uygulamalarda sıvaya yumurta akı karıştırılmıştır (Sözen ve Eruzun, 1992, s. 243-245).). Bu uygulama özellikle iç mekânda tercih edilmektedir. Kıtıklı sıva ise, dayanımı artırmak üzere saman, kireç, alçı ve çamurun bağlayıcı olarak kullanılmasıyla oluşturulmuştur. Alanda tamiratlar esnasında gerçekleştirilmiş özgün malzemeye aykırı çimento bazlı sıva uygulamaları da tespit edilmiştir.

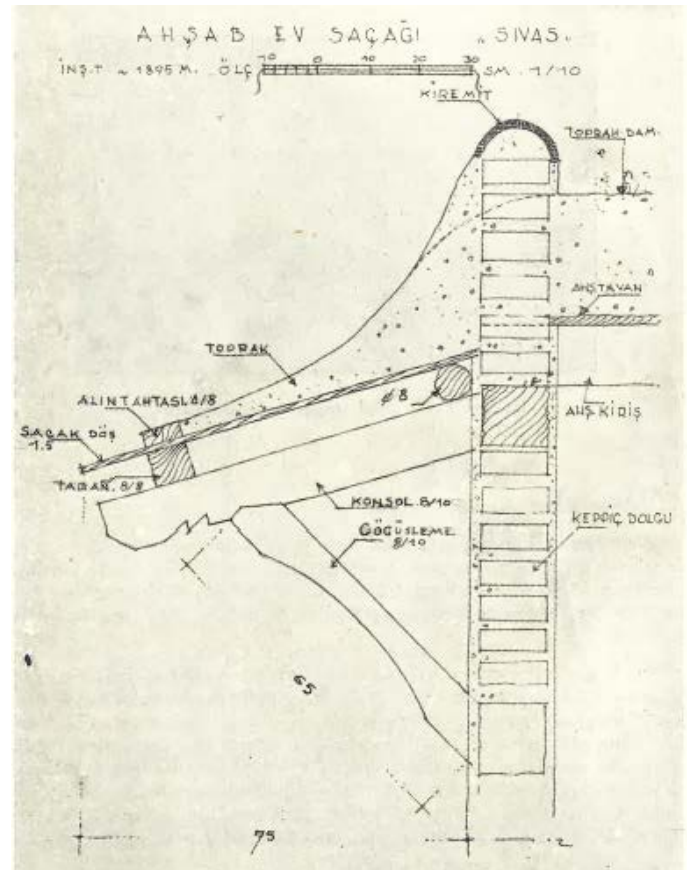

Şekil 15. Sivas geleneksel konutlarının saçak ve döşeme yapımını gösteren detay (Binan, 1952, s. 161)

Kiremit kaplı çatı uygulamasının bir zorunluluk olarak uygulanmasına kadar (Cuinet, 1892:664-665, aktaran Mahiroğulları, 1993:15), şehirde toprak damlı evler yaygın olarak uygulanmaktaydı. Binan'ın 1950'li yıllarda bir Sivas geleneksel konutunun yapım sistemini belgelediği detay çiziminde toprak dam uygulması ile ahşap ve kerpicin uygulama detayı okunabilmektedir (Şekil 15). Saha çalışması esnasında evlerin özgün çatı kaplamalarının tamiratlar esnasında değişime uğradığı gözlemlenmiştir. Çatı detayı incelenebilen konutlar arasında Şekil 15'deki toprak dam detayı uygulamasının günümüze ulaşan örneğine ulaşılamamıştır. Evlerin üst kat döşemesinin üzeri sıcak ve 
soğuk izolasyonu amacıyla bol samanlı $10 \mathrm{~cm}$ kalınlığında çamurla örtülmüştür. Kullanılan geleneksel örtü malzemesi alaturka kiremitler, Tokat yöresinden getirilmiştir (Üredi, K. 2009:19-48) İç mekanda hizmet birimlerinde özgün döşeme sıkıştırılmış topraktır. Diğer katlarda tabanlar döşeme kirişlerine zıt yönlü $15-20 \mathrm{~cm}$ genişlikte ahşap plaklarla kaplanmıştır. Tavan kaplamalarında yaygın uygulama çıtakari kaplama tekniğidir. Zengin süslemelere sahip tavan uygulamalarının örnekleri az sayıda günümüze ulaşmıştır. En sık görülen uygulama çıtalı ahşap tavandır. En az görülen örnek ise alçı malzemenin kabartılarak ve renklendirilerek işlenmesiyle oluşturulmuş örnektir (Şekil 16).

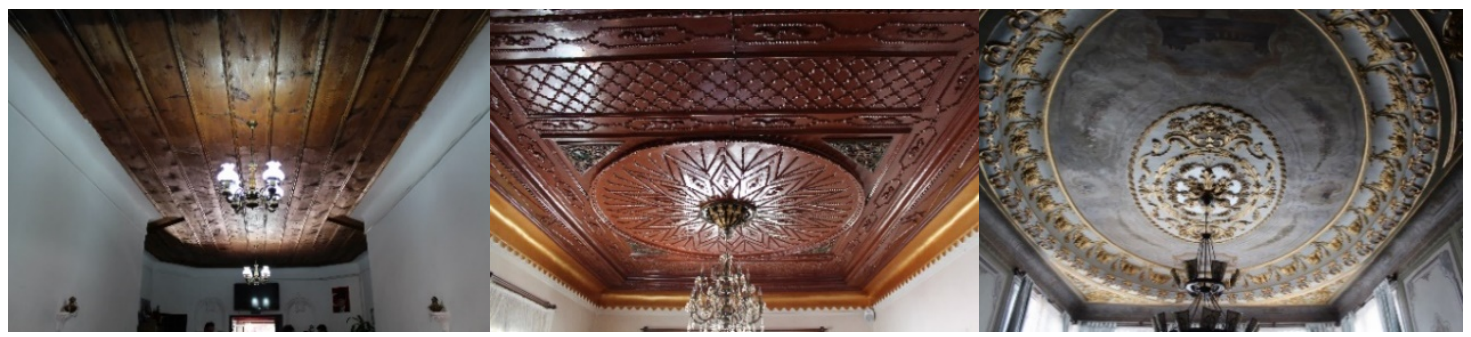

Şekil 16: Sivas konutlarında tavan kaplaması örnekleri sırasıyla: çıtalı ahşap tavan, göbekli ahşap oyma tavan ve alçı kaplama tavan (Gülhayat Kılcı)

\section{Sivas Geleneksel Konutlarının Yapısal, Değişmişlik ve Kullanım Durumu Analizleri}

Sivas geleneksel konutlarının yapısal durumu, değişmişlik durumu ve kullanım durumlarını analiz etmek ve korunma sorunlarını belirlemek amacıyla, Sivas kent merkezinde ayakta kalabilmiş, 38'i (\%36) tescilli 68'i (\%64) tescilsiz (Şekil 17), 106 geleneksel konutun tamamında tespit ve değerlendirme yapılmıştır.

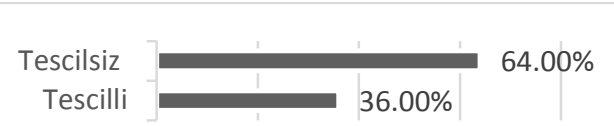

0.00\% $20.00 \% 40.00 \%$ 60.00\% $80.00 \%$

Şekil 17: Sivas Geleneksel Konutlarının Tescil Durumu

Yapısal durum bakımından; 106 konuttan 39'u (\%37) iyi, 40'ı (\%38) orta, 24'ü (\%22) kötü ve 3'ü (\%3) harap durumdadır (Grafik 2). Yapısal durum olarak iyi: taşıyıcı sistemi ve yapı elemanları müdahale gerektirmeyen, sadece bakım gerektiren ve kullanım açısından bir sorunu olmayan; orta: taşıyıcı sistemi müdahale gerektirmeyen ancak mimari elemanları onarım ve bakım gerektiren; kötü: taşıyıcı sisteminde ve mimari elemanlarından sorunları ve kayıpları olan, ivedi müdahale gerektiren yapıları; harap ise büyük çoğunluğu yok olmuş ve ancak rekonstrüksiyon müdahalesiyle ayağa kaldırılabilecek yapıları temsil etmektedir (Şekil 18).

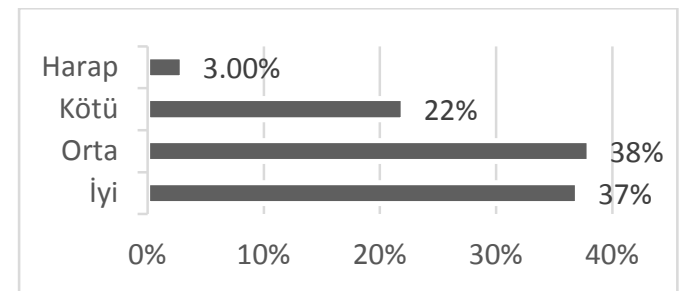

Şekil 18: Sivas Geleneksel Evlerinin Yapısal Durumu 
Cephelerin özgünlükleri; değişmemiş, az değişmiş ve çok değişmiş olmak üzere üç derecede belirlenmiştir. Dolu-boş oranları, biçim ve malzeme özellikleri korunan, yalnızca gerekli tadilatların yapıldığı konutlar değişmemiş; dolu-boş oranlarında ve malzemede değişiklik yapılmış ancak özgün cephe organizasyonunu korumuş yapılar az değişmiş; yapının özgünlüğünü kaybettirecek ölçüde müdahale edilmiş yapılar ise değişmiş olarak sınıflandırılmıştır. Bu bağlamda alandaki konutların 21'i (\%20) değişmemiş, 62'si (\%59) az değişmiş, 20'si (\%19) çok değişmiş olarak değerlendirilmiş, konutların 3'ünde (\%2) detaylı dış değerlendirme yapılamamıştır (Şekil 19-20).

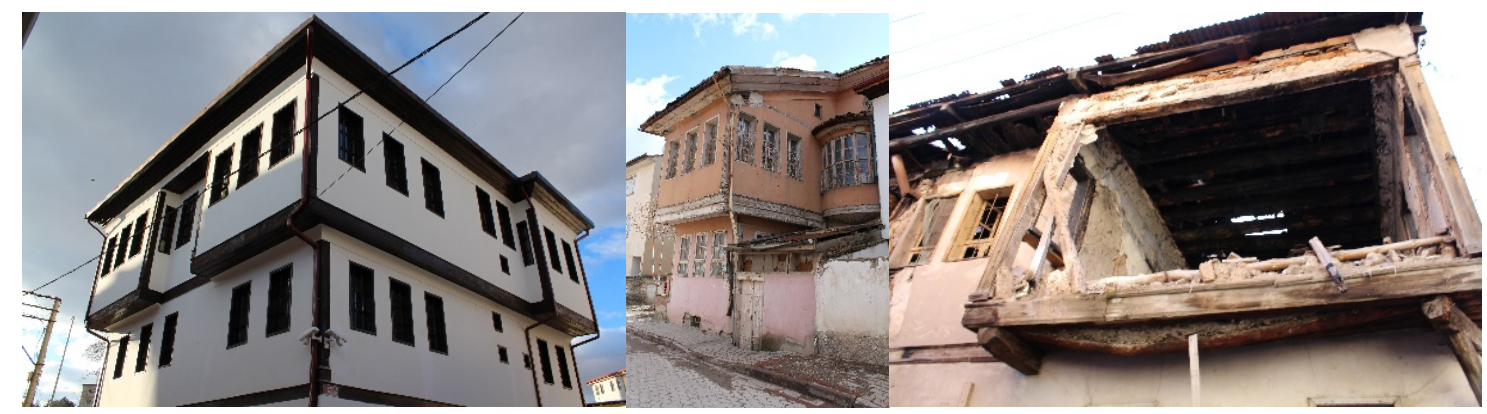

Şekil 19: Farklı yapısal durumlarda konut örnekleri (Gülhayat Kılcı)

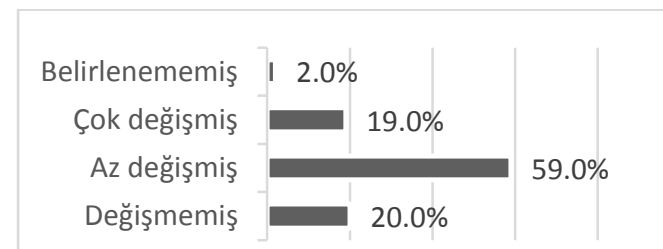

$0.0 \% 20.0 \% 40.0 \% 60.0 \% 80.0 \%$

Şekil 20: Sivas Geleneksel Konutlarının Dış Özgünlük Değerlendirmesi

Konutların 35'inin iç mekanına ulaşılarak tespit yapılabilmiştir. İç mekân özgünlükleri; değişmemiş, az değişmiş ve çok değişmiş olmak üzere üç derecede belirlenmiştir. Bu bağlamda, plan organizasyonu ve iç mekân elemanları özgün olarak günümüze ulaşmış olanlar değişmemiş, plan organizasyonunda şemayı ve okunurluğunu bozmayan (cam yüzeyle mekanın bölünmesi, kapı açılması gibi) müdahaleler yapılmış ve iç mekân elemanları değişmiş konutlar az değişmiş, plan şeması okunamayan geniş çaplı müdahale yapılmış yapılar çok değişmiş olarak değerlendirilmiştir. Buna göre konutların iç mekanlarının 12'si (\%34) değişmemiş, 19'u (\%54) az değişmiş, 4'ü (\%12) çok değişmiş olarak değerlendirilmiştir (Şekil 21-22).

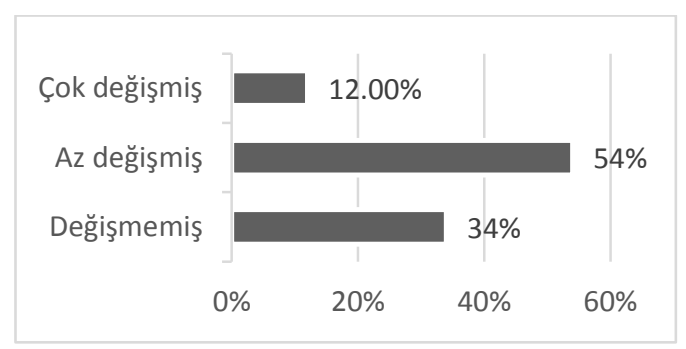

Şekil 21: Sivas geleneksel konutlarının iç mekân özgünlük değerlendirmesi 


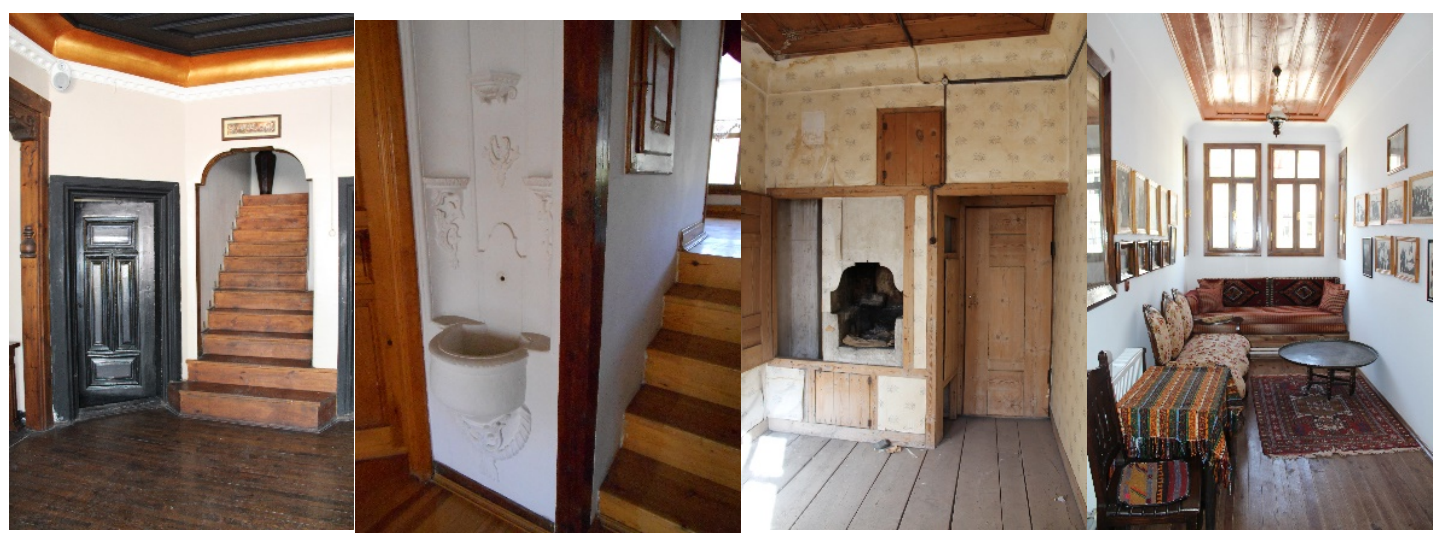

Şekil 22: Sivas geleneksel konutlarının iç mekân özgünlük durumlarından örnekler

Konutların kat yükseklikleri ile ilgili analiz sonucunda: tek katlı $2(\% 1,8)$, bodrum+zemin katlı $8(\% 7,5)$, zemin+köşklü $9(\% 8,4)$, zemin+1 katlı $48(\% 45,2)$, bodrum+zemin+1 katlı $28(\% 26,4)$, bodrum+zemin+köşklü $5 \quad(\% 4,7)$, zemin+1+köşklü $3 \quad(\% 2,8)$, bodrum+zemin+1+köşklü $1(\% 0,9)$, zemin+2 katlı $2(\% 1,8)$ adet konut tespit edilmiştir.

Konutların büyük bir bölümü özgün işlevi olan konut işlevi ile $(62(\% 58,4))$ kullanılmaya devam ederken, 25 adet $(\% 23,5)$ konut işlevsizdir. Yeni işlev verilmiş konutlardan 7 'si (\%6,6 vakıf, dernek ve oda gibi kurumların ofisi olarak, 3'ü $(\% 2,8)$ kültür evi, 2'si $(\% 1,8)$ restoran, 1'i $(\% 0,9)$ okul, 1'i $(\% 0,9)$ müze, 1'i $(\% 0,9)$ depo olarak kullanımaktadır. Konutlardan 4'ü $(\% 4,2)$ ise metruk durumdadır. (Şekil 23).

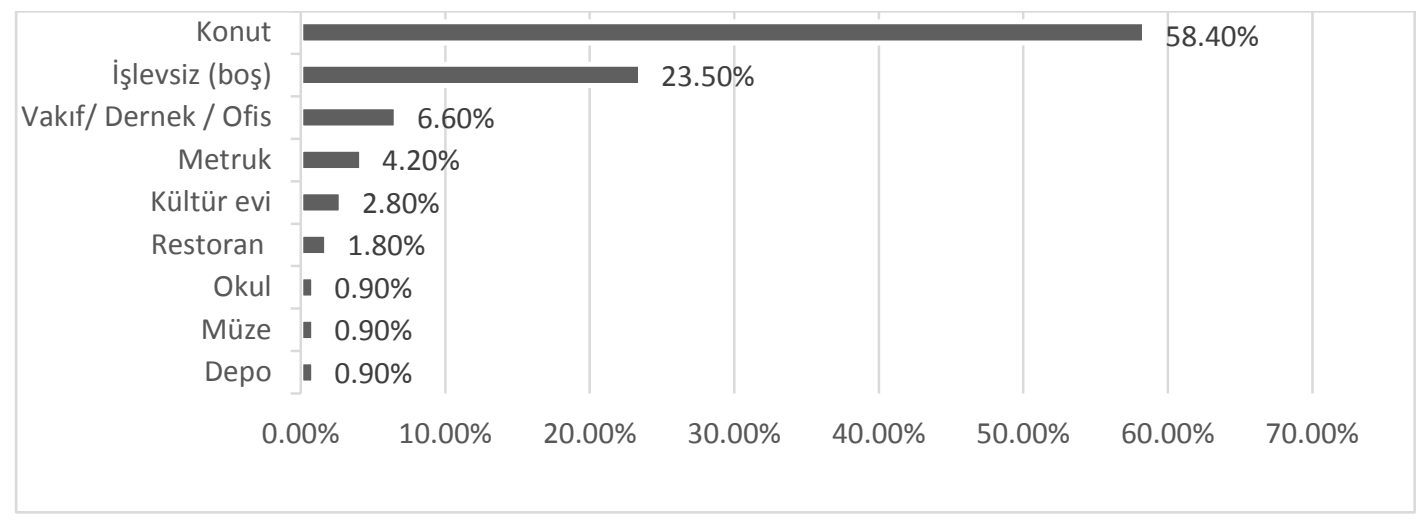

Şekil 23: Sivas konutlarının güncel fonksiyonları

\section{Sivas Geleneksel Konutlarının Korunma Sorunları}

1923 yılına ait bir fotoğraf, Sivas kalesi ve etrafındaki konut dokusunun ilişkisini göstermektedir (Şekil 24). Şehre hâkim olan geleneksel konut dokusu 20. yüzyılın ortalarına doğru tahrip edilmeye başlamıştır. 


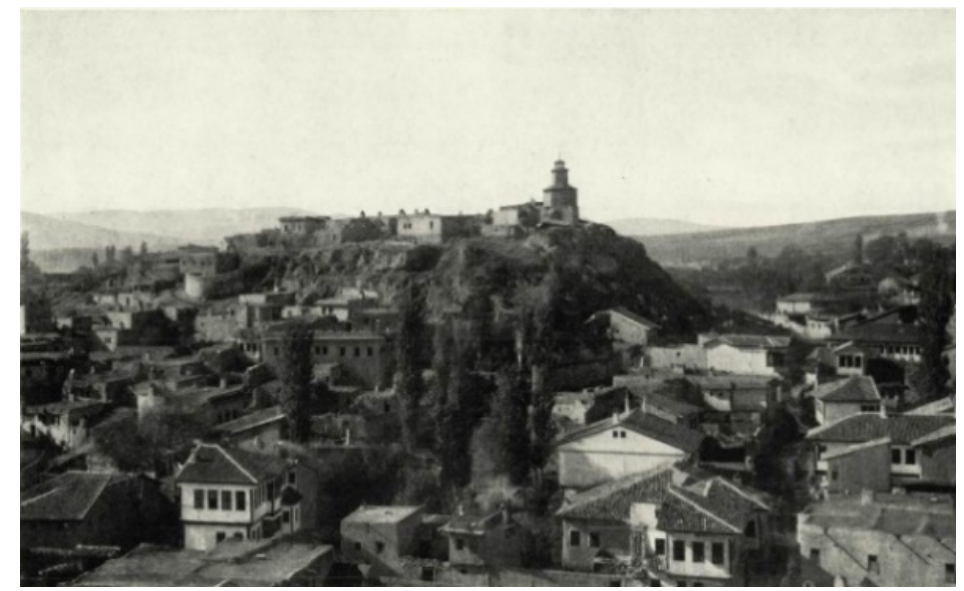

Şekil 24: Sivas kent yerleşimini gösteren Fotoğraf -1923 (Anonim, URL 4)

Anıtsal yapılar korunmuştur ancak geleneksel konutların kültür mirası olarak kabulü, 1970'li yıllarla korumadaki kuramsal yaklaşımın kapsamının genişlemesi ile gerçekleşebilmiştir. Konutların mimari kültür mirası olarak kabulü ve bu miras ögelerinin tescili konusunda geç kalınması sebebiyle, özellikle 20. yüzyılın ikinci yarısında hızlanan kentleşme hareketlerinin sebep olduğu kayıplara engel olunamamış, şehir bu anlamda büyük kayıplar vermiştir. Bugün Anadolu'daki pek çok tarihi kentte geleneksel dokular yeni yapılaşmaların baskısı altındadır.

Geleneksel konutlar ve geniş açık alanları, kullanıcı eliyle ya da yerel yönetimlerin uyguladığı bayındırlık faaliyetleri (yol genişletmek, yol açma, yeni yapı inşası gibi) ve kentsel dönüşüm çalışmalarıyla tahrip edilmiştir. Hızla üretilen tekdüze yapılaşmanın giderek artmış olması sonucu özgün sokak dokusu bozulmuş, geleneksel konut dokusundaki süreklilik yok olmuştur. Yok olmaya yüz tutmuş geleneksel konut örnekleri, yapım sistemi ve ölçek açısından dokuya aykırı yeni konutlar arasında sıkışmıştır (Şekil 25). Yeni yapılar ve geniş yollar yapıların açık alanlarını işgal etmiş, konutların yolla olan özgün ilişkisini değiştirmiştir.

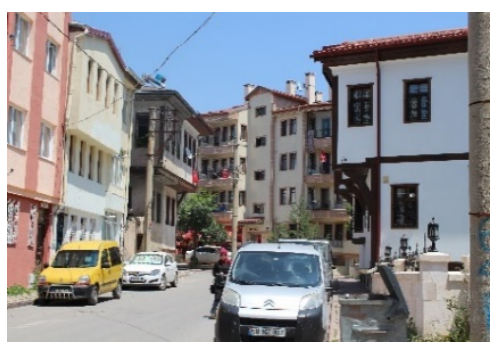

Şekil 25: Sivas geleneksel evlerinde çevresel koruma sorunları (sırasıyla: yoğun yeni yapılaşma; metruk kalan geleneksel konutlar; yeni yapılaşmanın geleneksel konutlara baskısı)

(Gülhayat Kılcı)

Kentlerde yenilemenin sonucu olarak hızla çoğalan apartmanlar, özellikle varlıklı ailelerin 'kata çıkma' arzusuyla gözdesi olmuştur. Böylelikle boşalan geleneksel konutlar, zamanla alt gelir gruplarının uygun fiyatlı kiraladıkları konutlar halini almıştır. Yapıyla kurulan duygusal bağ ve aile mirası anlayışı korumayı olumlu yönde etkileyen bir ilişkidir. Kullanıcıların değişmesi geleneksel konutlarda bakım ve onarım problemlerinin artmasının ve giderek tahrip olmalarının yolunu açmıştır. İklim koşulları sebebiyle kış aylarında ısınma problemiyle baş etmek amacıyla yapıların özgün açıklıkları değiştirilmiş ya da uyumsuz malzemelerle kaplanmıştır. Az bütçeyle ya da 
eldeki malzeme kullanılarak yapılan müdahaleler, yapı elemanları ve malzemelerinin özgün ile uyumsuz şekilde değiştirilmesine sebep olmuştur (Şekil 26).
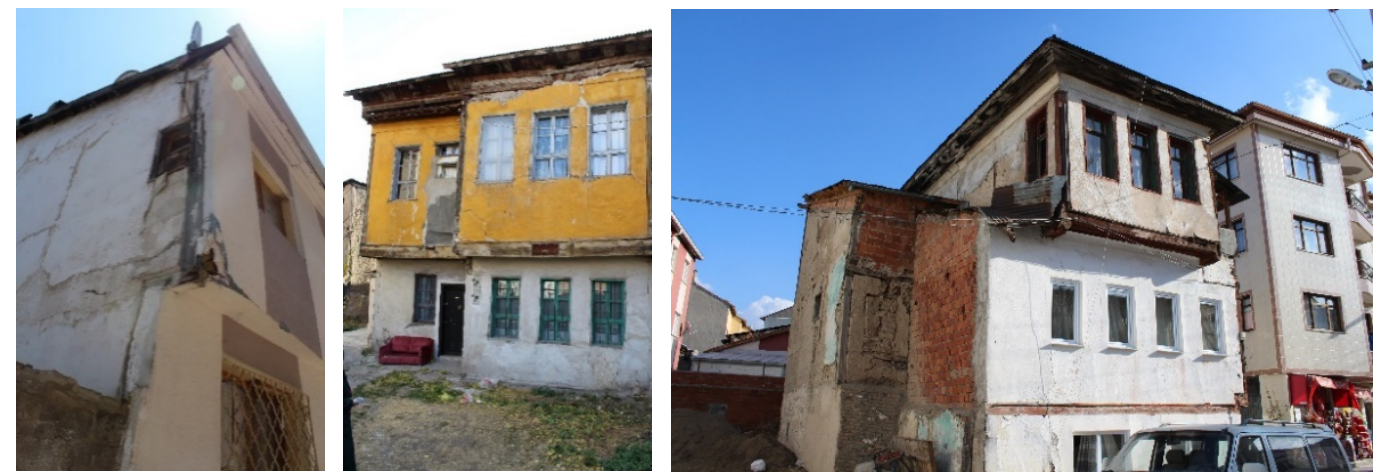

Şekil 26: Sivas geleneksel konutlarının yapı ölçeğinde korunma sorunları (sırasıyla: niteliksiz onarım; özgün açıklıkların kapatılması; yapının özgün yapısına aykırı malzeme kullanımı)

(Gülhayat Kılcı)

Kentte süregelen planlama faaliyetlerine bakıldığında, mevcutta koruma amaçlı imar planının bulunmadığı görülmektedir. Bayındırlık faaliyetleri sadece konutları değil çevresini de etkileyerek konutları bağlamından koparmıştır. Dereler Sivas şehrinin morfolojisinin oluşumunda önemli referanslar olmuştur. Şehre ait özgün dokuyu gösteren eski fotoğraflarda da görülebileceği gibi konutlar derelerin iki yanında konumlanmış, su, şehir yaşamına karışmış bir haldedir. Ancak yol çalışmaları kapsamında bu dereler yer altında bırakılarak hem şehir peyzajını hem de hafızasını tahrip etmiştir (Şekil 28-29). Günümüze ulaşan haliyle ise konutlar sokak ve yapı ölçeğinde korunabilmektedir. Şehirde bu bağlamda bir sit alanı belirlenmemiş, I. II. ve III. Dereceden arkeolojik sit alanları ve bu alanlarda konumlanan geleneksel konutlar bulunmaktadır (Şekil 27).

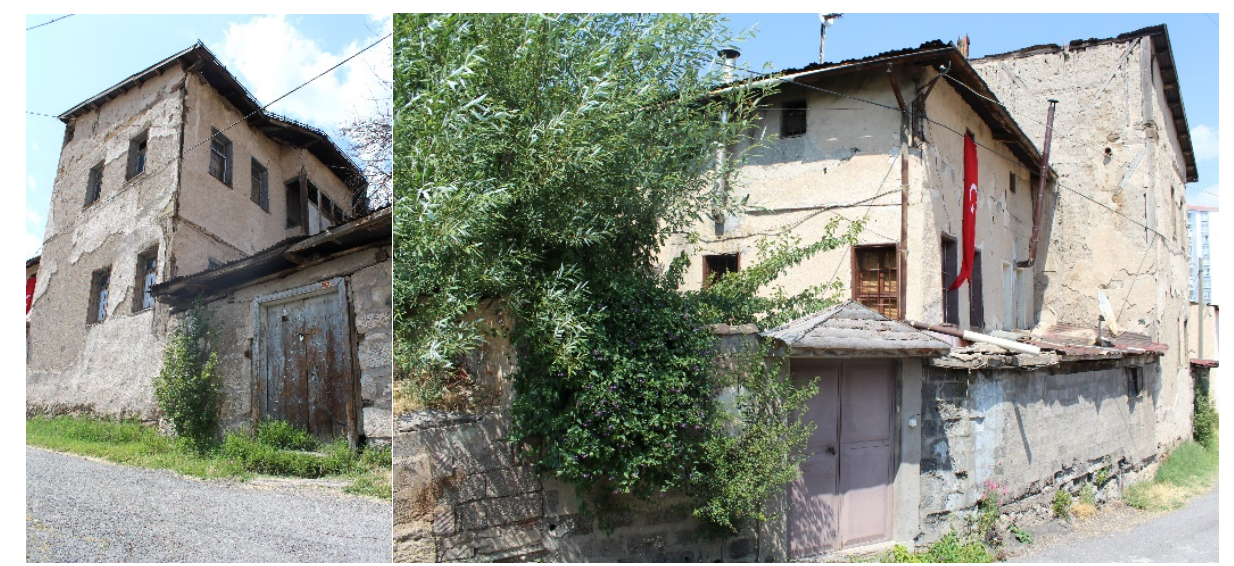

Şekil 27: I. Derece arkeolojik sit alanında konumlanan geleneksel konutlar 

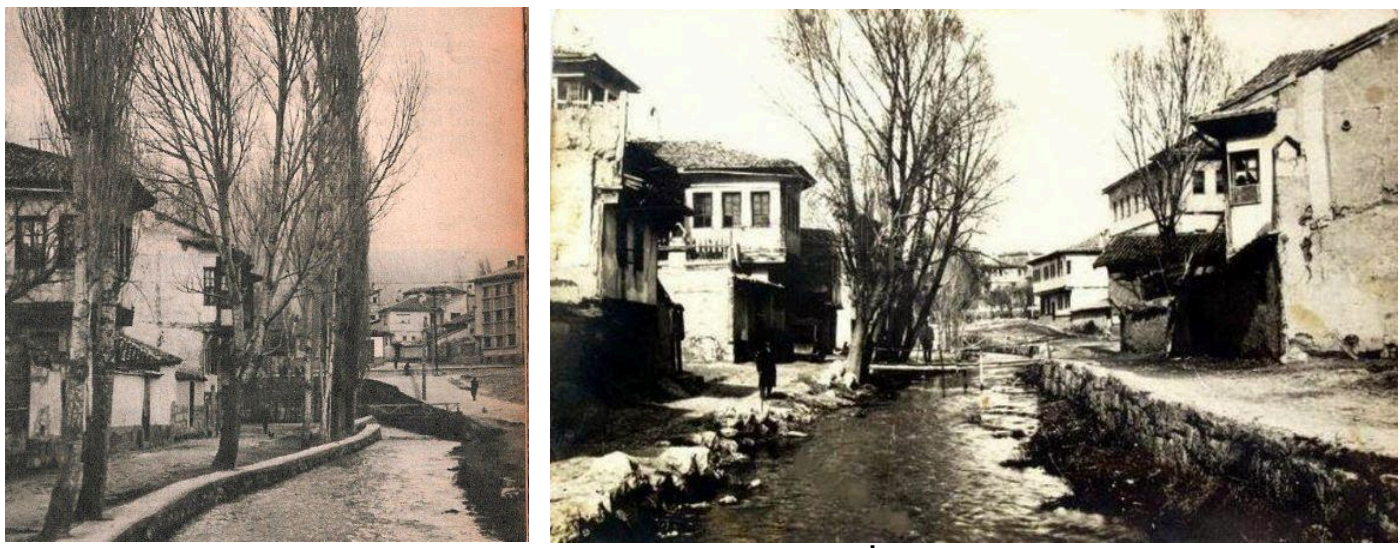

Şekil 28. Sivas geleneksel konutlarının suyla Ílişkisi (Anonim, URL 5)

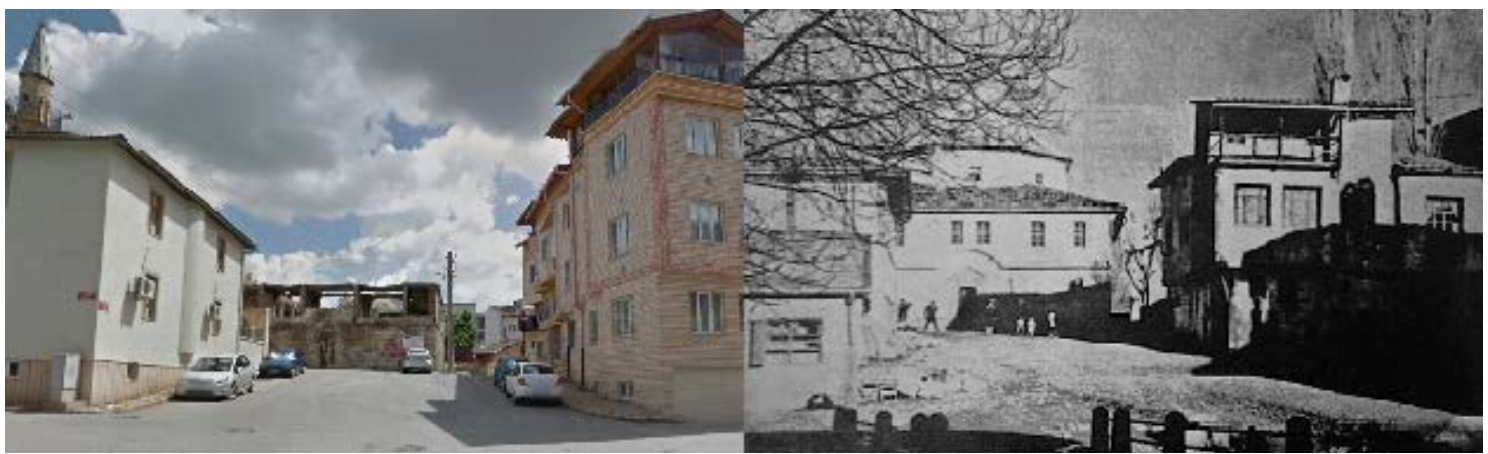

Şekil 29. Solda Şirinoğlu Hamamı-2019 yılı, sağda 1964 yılı fotoğrafı sokak dokusu ve dereyle ilişkisinin değişimi (Google Street, Anonim)

Çalışma alanında korumaya dair tespit edilen en önemli problem halktaki koruma bilincinin eksikliğidir. Özgün işleviyle geleneksel konutlarını kullanmaya devam eden kullanıcıların (62 konut) koruma bilinçlerini ölçmeyi hedefleyen sosyal anketler sonucunda katılımcıların \% 61'inin tarihi çevre koruma ve tescil kavramları ile ilgili bilgileri olmadığı tespit edilmiştir. Katılımcıların \% 39'u ise tarihi çevreyi korumaya dair bilinçli olarak yaşadıkları konutun korunması gerektiğini belirtmişlerdir. Yeniden işlevlendirilen (büro, vakıf, oda, dernek vs.) geleneksel konut kullanıcılarının tamamının (15 yapı) yapıları korumaya değer görmesi koruma bilinçlerinin yüksek olduğunu göstermiştir. Geriye kalan 25 konut işlevsiz ve 4 konut metruk durumdadır. Tescilli konutlar genellikle daha büyük ölçekli ve bakımlı konutlar olmakla birlikte kullanıcı profili de bu bağlamda değişmektedir. Tescilsiz ve çürümeye terk edilmiş geleneksel konutlarda gelir düzeyi düşük kiracıların konuta makul bütçeli barınma birimi olarak bakmakta ve yapının mimari özelliklerine değer atfetmemektedir. Daha iyi ekonomik koşullara erişmeleri durumunda daha yeni bir konutta barınma isteklerini belirtmişlerdir. Yine tescilsiz konutlar arasında mülk sahibinin oturduğu örneklerde aidiyet duygusunun kuvvetli olması sebebiyle hatıra değeri, yapı ve açık alanı ile birlikte kullanım değeri, komşuluk ilişkilerinin yerleşik olmasından kaynaklı sosyal değer vurgulanmıştır.

\section{Değerlendirme ve Sonuç}

Hızlı ve yoğun kentleşme faaliyetleri neticesinde tüm şehirlerimizde oluşan sağlıksız kentsel mekanlar göz önüne alındığında geleneksel konutlar; gabarileri, dış mekanla ve doğayla kurdukları ilişkileri ve kullanıcılarına bıraktıkları nefes alacak alanlarla yeni yapılaşmaya referans olabilecek potansiyeldedir. Alanda yürütülen çalışma sonucunda kent merkezinde 106 geleneksel konutta dış, 35 konutta iç tespit ve değerlendirmelerin 
mevcut olduğu envanter çalışması yapılmıştır. Bu bilgiler ışığında Sivas geleneksel konutlarının mimari özelliklerine dair, plan tipolojisi, cephe tipolojisi, yapım sistemi ve malzeme kullanımı ve mimari eleman bilgileri aktarılmıştır.

Yapılan tespitler sonucunda 106 geleneksel konutun 38'i (\%36) tescilli 68'i (\%64) tescilsiz olup yapısal olarak 39'u (\%37) iyi, 40' । (\%38) orta, 24'ü (\%22) kötü ve 3'ü (\%3) harap durumdadır. Konutların özgünlük değerlendirmelerinde dış özelliklerine göre $21^{\prime} \mathrm{i}$ (\%20) değişmemiş, 62'si (\%59) az değişmiş, 20'si (\%19) çok değişmiş; iç mekân özellikleri açısından 12'si (\%34) değişmemiş, 19'u (\%54) az değişmiş, 4'ü (\%12) çok değişmiştir. Konutların kat sayıları ise şöyledir: tek katlı $2(\% 1,8)$, bodrum+zemin katlı 8 $(\% 7,5)$, zemin+köşklü $9(\% 8,4)$, zemin+1 katlı $48(\% 45,2)$, bodrum+zemin+1 katlı 28 $(\% 26,4)$, bodrum+zemin+köşklü $5 \quad(\% 4,7)$, zemin+1+köşklü $3 \quad(\% 2,8)$, bodrum+zemin+1+köşklü $1(\% 0,9)$, zemin+2 katlı $2(\% 1,8)$ adet konut bulunmaktadır. Konutların 62 adeti $(\% 58,4)$ özgün işlevinde devam etmektedir, 25 adet $(\% 23,5)$ konut ise işlevsizdir. Diğer konutların fonksiyonları ise 7'si (\%6,6 vakıf, dernek ve oda gibi kurumların ofisi olarak, 3'ü $(\% 2,8)$ kültür evi, 2'si $(\% 1,8)$ restoran, 1'i $(\% 0,9)$ okul, 1'i $(\% 0,9)$ müze, 1'i $(\% 0,9)$ dağılım göstermektedir. Konutlardan 4'ü $(\% 4,2)$ ise metruk durumdadır.

Şehrin eski fotoğraflarında anıtsal yapıların yanı sıra geleneksel konutlar ve şehrin içinden geçen derelerle kurdukları ilişki ile ağaçlar şehrin kimliğini tanımlayan ögeler olarak göze çarpmaktadır. Geleneksel konutların birçoğu geri döndürülemez biçimde yok edilmiştir. Ancak, doğal kültürel miras olarak dereler tekrar şehre kazandırılmalı, kentle bütünleşmesi sağlanmalı ve şehrin hafızası gün yüzüne çıkarılmalıdır.

Çalışmanın temel amacı sayıları oldukça azalmış geleneksel konutların tespiti ve özelliklerinin geleceğe aktarılması olmuştur. Tescilsiz konutların düşük gelirli kullanıcılar tarafından kullanılıyor olması yapılara niteliksiz müdahale edilmesine sebep olmaktadır. Bu bağlamda tespit ve tescillerin kent genelinde hızlandırılarak kapsamlı hale getirilmesi gerekmektedir. Şehirde bugüne kadar kapsamlı bir koruma imar planı uygulanmamıştır. Bölgesel olarak geliştirilen koruma projeleri kayıpların hızlanmasına fırsat tanımıştır. Geleneksel konut dokusunun yoğunlaştığı mahallelerde geleneksel konutlar yeni yapılaşmaların baskısı altındadır. İmar planlamaları esnasında yapılara yaklaşma mesafeleri göz önüne alınarak yeniden düzenlenmelidir. Alanda yürütülen çalışmalar esnasında yapılan sosyal anket sonuçları konutların özgün kullanıcılarının büyük oranda değişmiş olduğunu ve mevcut kullanıcıların koruma bilincinin yeterli olmadığını göstermiştir. Yapıların fiziksel ve sosyal sürdürebilirliğinin sağlanması için ön koşul, yerel halkın kültürel mirasın, sahip olduğu değerlerin ve korunmasının önemi konusunda bilinçlendirilmesidir. Bu bağlamda yerel sivil toplum kuruluşlarının faaliyetleri desteklenmeli, şehrin değerlerini anlatacak projelere önem verilmelidir. Şehrin doğal ve kültürel potansiyelini bir arada ortaya koyacak; dünya, ülke, bölge ve yakın çevre ile ilişkilendirilmiş koruma ve geliştirme projeleri, kamu yararını göz önünde bulundurarak çok boyutlu, her bir yapı özelinde ve disiplinler arası özellikte olmalıdır.

\section{Kaynaklar}

Akbulut, G. Sivas Şehrinin Tarihi Coğrafyası. Cumhuriyet Üniversitesi Sosyal Bilimler Dergisi, 2009, 35(2), 213.

Bilget, N. B., Sivas Evleri. Kültür Bakanlığı, 1992, (Vol. 1403), s. 45. 
Binan, M., Türk Saçak ve Kornişleri: İlk Çağlar, Selçuk ve Osmanlı Devirleri, Yabancı Mimari Devirlerle Mukayeseler. Basılmış Doçentlik Tezi, Pulhan Matbaası İstanbul, 1952, s.157-161.

Eldem, S. H., Türk Evi Plan Tipleri. İstanbul Teknik Üniversitesi Mimarlık Fakültesi, Pulhan Matbaası İstanbul, 1954, s. 11-127.

Gabriel, A., La Grande Mosquee. Monuments Turcs d'Anatolie. Paris: E. De Boccard 1934, s. 135.

ICOMOS, Geleneksel Mimari Miras Tüzüğü, ICOMOS 12. Genel Kurulu, Meksika, 1999.

Kuban, D., Türk 'Hayat'lı Evi, Mısırı Matbaacılık. İstanbul 1995, s. 16.

Mahiroğulları, A., XIX. Yüzyılın Son Çeyreğinde Sivas'a Gelen Bir Fransız Seyyah: Vital Cuinet. Revak Dergisi, 1993, s.14-20.

Mahiroğulları, A., Seyyahların Gözüyle Sivas-Voyage dans le Pont (Pontus'a Seyahat) Seyahatnamesi Sivas 1902. İstanbul 2001, s. 167.

Sözen, M., Eruzun, C., Anadolu'da Ev ve İnsan. Creative Yayıncılık ve Tanıtım, İstanbul 1992: s. 243-245.

Uzunçarşıı, İ. H., Edgüer, T., Rıdvan N. (Yayına hazırlayan), "Sivas Şehri", Türk Tarih Kurumu, Ankara 2014, s.12-31.

Üredi, K., Şehrin Ahşap Zamanı. Ötüken Neşriyat, İstanbul 2014, s.19-48.

İnternet Kaynakları

URL.1 http://www.sivaskaleprojesi.com/ Son erişim tarihi: 11/5/2020 Saat. 20:00

URL.2 https://www.sivaskulturenvanteri.com/sivas-kalesi-topraktepe/ Son erişim tarihi: $11 / 5 / 2020$ Saat $20: 30$

URL.3

http://www.sosyalpaylar.com/sivas_foto\%C4\%9Fraflar\%C4\%B1/eski_sivas_siyah_bey az_foto\%C4\%9Fraflar\%C4\%B1_18.html Son erişim tarihi: 12/7/2020 Saat. 16.00

URL.4 www.sivas.li/2015/04/tavra-deresi.html Son erişim tarihi: 12/7/2020 Saat: 16:30

URL.5 http://wowturkey.com/forum/ Son erişim tarihi: 7/12/2020 Saat: 16:30 